Cite as:

Costa-Machado, A. R. M.; Freitas, L. A. P. de; Mendiola, J. A.; Ibáñez, Elena "Copaifera langsdorffii supercritical fluid extraction: Chemical and functional characterization by LC/MS and in vitro assays" Journal of Supercritical Fluids 100: 86-96 (2015) http://dx.doi.org/10.1016/j.supflu.2015.02.028

\title{
Copaifera langsdorffii supercritical fluid extraction: chemical and functional characterization by LC/MS and in vitro assays.
}

Ana R. M. Costa ${ }^{\mathrm{a}, \mathrm{b}}$, Luís A. P. Freitas ${ }^{\mathrm{a}}$, J. Mendiola $^{\mathrm{b}}$, E. Ibáñez $^{\mathrm{a} *}$

${ }^{a}$ Faculdade de Ciências Farmacêuticas de Ribeirão Preto, Núcleo de Apoio à Pesquisa em Produtos Naturais e Sintéticos, Universidade de São Paulo, Via do Café, s/n, Campus USP, Ribeirão Preto, 14040-903, SP, Brazil.

${ }^{\mathrm{b}}$ Bioactivity and Food Analysis Department, Food Research Institute (CIAL-CSIC), Universidad Autónoma de Madrid, Calle Nicolás Cabrera, 9 Cantoblanco, 28049 Madrid - Spain.

* Corresponding author Prof. Elena Ibáñez Bioactivity and Food Analysis Department

15 Food Research Institute (CIAL-CSIC) Nicolás Cabrera, 9 Campus UAM Cantoblanco 28049 Madrid - Spain Email: elena.ibanez@csic.es Phone.: 00-34-91-0017 956

20 Fax: 00-34-91-0017 905 
Cite as:

Costa-Machado, A. R. M.; Freitas, L. A. P. de; Mendiola, J. A.; Ibáñez, Elena "Copaifera langsdorffii supercritical fluid extraction: Chemical and functional characterization by LC/MS and in vitro assays" Journal of Supercritical Fluids 100: 86-96 (2015) http://dx.doi.org/10.1016/j.supflu.2015.02.028

ABSTRACT

30 Copaifera langsdorffii is a native Brazilian plant containing important amounts of polyphenols and diterpenes with biological activity. To obtain extracts enriched in these two types of compounds, supercritical fluid extraction (SFE) conditions have been optimized by using a Response Surface Methodology (RSM) and considering as a factors: extraction pressure and temperature and percentage of co-solvent (ethanol). The response variables selected were the

35 concentration of the two most representative compounds in $C$. langsdorffii, kaurenoic acid (diterpenic acid) and quercitrin (glycosylated flavonol), total flavonoids content, and antioxidant activity (measured by DPPH and TEAC assays). According to the statistical analysis of the experimental design, extraction temperature and ethanol percentage were the main factors influencing the selectivity towards the extraction of the target compounds. Two optimized extracts were obtained: 1) containing high amount of total flavonoids, high concentration of quercitrin and low $\mathrm{EC}_{50}$ for the DPPH assay, named HQE- High Quercitrin Extract (100 bar, $70^{\circ} \mathrm{C}$ and $50 \%$ of ethanol, in the region of gas-expanded liquids, GXLs) and 2) containing high value of kaurenoic acid extract, named HKAE-High Kaurenoic Acid Extract, $\left(390\right.$ bar, $70^{\circ} \mathrm{C}$ and pure $\mathrm{CO}_{2}$ ). Chemical characterization by LC/MS of HQE showed the presence of galloylquinic acids and flavonoids while, on the other hand, HKAE presented only nonpolar compounds such as kaurenoic acid. Moreover, a solid-liquid extraction (SLE) with methanol was carried out as a benchmark protocol for comparative purposes. SFE presented approximately 10-fold higher content of total flavonoids than the extracts obtained by SLE.

50 Keywords: Copaifera langsdorffii, supercritical fluid extraction, response surface methodology, flavonoids, kaurenoic acid, quercitrin, antioxidant activity 
Cite as:

Costa-Machado, A. R. M.; Freitas, L. A. P. de; Mendiola, J. A.; Ibáñez, Elena "Copaifera langsdorffii supercritical fluid extraction: Chemical and functional characterization by LC/MS and in vitro assays" Journal of Supercritical Fluids 100: 86-96 (2015) http://dx.doi.org/10.1016/j.supflu.2015.02.028

\section{Introduction}

The Copaifera sp genus belongs to the botanical family of Legumonaseae Juss., sub-family Caesalpinioideae Kunth., but it can be also found in the literature by its previous classification: in Brazil more than 20 species from the Copaifera sp genus have been described, all of them with similar therapeutic claims $[1,2]$. Several scientific studies on Copaifera $s p$ reported important pharmacological activities, among them: anti-inflammatory, analgesic, antimicrobial, antitumor, antioxidant, wound healing, gastro protective, anti-helminthic, leishmanicide, trypanomicide and muscle relaxant [1-6].

Among the different species of Copaifera, C. langsdorffii has been suggested as a promising natural source of products for the pharmaceutical market. The oral use of C. langsdorffii leaves was reported to be effective in relieving pain and eliminating renal calculi in nephrolitiasic patients [7]. The in vitro disruption of oxalate crystals and the in vivo assay using ethylene glycol-induced nephrolithiasis in rats was reported by Oliveira and co-workers employing $C$. langsdorffii leaves' extracts [8]. An in vivo study reported a decrease of the number and weight in calcium oxalate calculi previously introduced in the bladder of rats treated with hydroethanolic extract of C. langsdorffii leaves [9].

Phytochemical investigations on $C$. langsdorffii leaves reported 6 to $10 \%$ of phenolic compounds, $3 \%$ of the amino acid N-methyl-trans-4-hydroxy-L-proline and sesquiterpenes as $\alpha$ cubebene, $\alpha$-copaene, ciperene, $\beta$-copaene, caryophyllene, $\beta$-humulene, muurolene, $\beta$-selinene, $\delta$-cadinene and $\gamma$-cadinene [10-12]. Furthermore, recent works reported the isolation and identification of kaurenoic acid, caryophyllene oxide, kaurenol, hydroxy-labdaenoic acid, quercitrin and afzelin [13]. Quercitrin (quercetin-3-O-rhaminoside) is a glycosylated flavonol with a molecular weight of $448.38 \mathrm{~g} / \mathrm{mol}$, practically insoluble in cold water, moderately soluble 
Cite as:

Costa-Machado, A. R. M.; Freitas, L. A. P. de; Mendiola, J. A.; Ibáñez, Elena "Copaifera langsdorffii supercritical fluid extraction: Chemical and functional characterization by LC/MS and in vitro assays" Journal of Supercritical Fluids 100: 86-96 (2015) http://dx.doi.org/10.1016/j.supflu.2015.02.028

in hot water and freely soluble in ethanol [14]; several activities have been described for quercitrin, such as antioxidant $[15,16]$, anti-inflammatory and anti-complement system $[17,18]$, enzymatic inhibition of HMG-CoA reductase and angiotensine-I converser [19], tyrosinase [20], cyclooxygenase-2 [15], myeloperoxidase [21] and inhibition of substances such as nitric oxide [15]. Moreover, in a recent study [22] galloylquinic acids have been identified as compounds present in C. langsdorffii leaves. It is well know that galloylquinic acids are very good antioxidant compounds since they can present from one to four molecules of gallic acid linked to a molecule of quinic acid.

On the other hand, diterpene acids, such as kaurenoic acid (also known as ent-kaur-16-en-18-oic acid), are also an important part of $C$. langsdorffii chemical compounds. Kaurenoic acid (Figure 1) presents a molecular weight of $302.45 \mathrm{~g} / \mathrm{mol}$ and a pKa value of $4.70 \pm 0.40$, being soluble in hexane and ethyl acetate [23]; diterpenes from kaurane series present many biological effects such as antimicrobial, antifungal [24], anti-inflammatory [25], vasodilatory [26], wound healing [27] and anti-psoriasis [28]. Besides, some previous studies on the oil, extracts, fractions and isolated substances, such as kaurenoic acid, from the Copaifera sp genus reported antitumor activity [29-35].

Extraction protocols for plant antioxidant phenolic compounds are very diverse due to the variation and complexity of phenolic substances and to the variety of vegetable matrices. The extraction yield, phenolic content and antioxidant activity of the extracts are strongly dependent not only on the specific plant material and its bioactive components, but also on the solvent and extraction method employed [36]. There are several extraction processes described in the literature, ranging from more traditional such as maceration, percolation and Soxhlet extraction [37] to modern extraction methods such as those based on the use of compressed fluids (including supercritical fluids (SCF), gas-expanded liquids (GXLs), pressurized liquids and 
Cite as:

Costa-Machado, A. R. M.; Freitas, L. A. P. de; Mendiola, J. A.; Ibáñez, Elena "Copaifera langsdorffii supercritical fluid extraction: Chemical and functional characterization by LC/MS and in vitro assays" Journal of Supercritical Fluids 100: 86-96 (2015) http://dx.doi.org/10.1016/j.supflu.2015.02.028 subcritical water extraction) [38]. Supercritical fluid extraction (SFE) offers considerable advantages compared to traditional extraction processes because it provides higher selectivity, shorter extraction times, higher efficiency and do not use toxic organic solvents avoiding the environment and sample contamination [39, 40]. SFE has been largely applied to extract different chemical constituents from plants including low [41] and high to medium polarity

105 compounds (such as phenolics) [39, 40, 42]. Furthermore, to our knowledge this extraction process has never been used to evaluate the compounds' extraction profile from Copaifera sp leaves. Moreover, since the Copaifera genus presents polyphenols and diterpene compounds, both with important biological activities, the goal of the present work has been the study and optimization, via experimental design, of the supercritical fluid extraction of two representative

110 compounds of these groups: kaurenoic acid and quercitrin, from the C. langsdorffii leaves.

\section{Materials and methods}

\subsection{Materials}

The leaves of the Copaifera langsdorffii Desf., Fabaceae, tree were collected at the Ribeirão Preto Campus of the University of São Paulo, SP, Brazil in July, 2012 and a voucher specimen

115 (SPFR 10120) was deposited in the herbarium of the Faculdade de Filosofia, Ciência e Letras de Ribeirão Preto, University of São Paulo. The herbal material was cleaned and dried in ventilated atmosphere of $30 \pm 5^{\circ} \mathrm{C}$ temperature, milled in a cutting mill to obtain particles between 0.5 to 1.0 $\mathrm{mm}$ and stored in a closed plastic bag in fresh and dried environment at $25^{\circ} \mathrm{C}$ until its use.

The kaurenoic acid standard was kindly given by the Laboratório de Farmacognosia from Faculdade de Ciências Farmacêuticas de Ribeirão Preto and the quercitrin standard was acquired from Sigma Aldrich (Madrid, Spain). 
Cite as:

Costa-Machado, A. R. M.; Freitas, L. A. P. de; Mendiola, J. A.; Ibáñez, Elena "Copaifera langsdorffii supercritical fluid extraction: Chemical and functional characterization by LC/MS and in vitro assays" Journal of Supercritical Fluids 100: 86-96 (2015) http://dx.doi.org/10.1016/j.supflu.2015.02.028

Acetonitrile (LC-MS quality, LabScan, Gliwice, Poland), water (purified using a Milli-Q system,

Millipore Corporation, Billerica, USA) and acidified water with phosphoric acid (Sigma-Aldrich,

Madrid, Spain) were used as mobile phases for HPLC analysis.

125 The solvents used in the supercritical extraction process were $\mathrm{CO}_{2}$ premier quality provided by Carburos Metálicos (Air Products Group, Madrid, Spain) and ethanol absolute 99\% provided by Panreac Quimica S.A. (Barcelona, Spain). Methanol was purchased from Sigma-Aldrich (Madrid, Spain).

2,2-Diphenil-1-pycril hydrazyl hydrate (DPPH, 99\%), gallic acid, 6-hydroxy-2,5,7,8-

130 tetramethylchroman-2-carboxylic acid (Trolox, $\geq 97 \%$ ), 2,2'-azino-bis(3-ethylbenzothiazoline-6sulphonic acid (ABTS, $\geq 99 \%$ ) and $\mathrm{AlCl}_{3}$ anhydrous were purchased from Sigma-Aldrich (Madrid, Spain).

\subsection{Solid-liquid extraction}

A solid-liquid extraction (SLE) was performed as a reference extraction in order to compare the

135 results of yield, total flavonoids, kaurenoic acid and quercitrin concentration and antioxidant activities with the extracts obtained by SFE. For that, $1 \mathrm{~g}$ of the dried milled leaves of $C$. langsdorffii was weighed in a flask and added of $50 \mathrm{~mL}$ of methanol. The extraction was kept for $24 \mathrm{~h}$ at room temperature under shaking of $150 \mathrm{rpm}$. After this time, the extracts were filtered and dried under vacuum.

\subsection{Supercritical fluid extraction}

Supercritical fluid extractions were performed in a homemade supercritical fluid extractor using pumps for $\mathrm{CO}_{2}$ and ethanol PU2080 from Jasco (Tokyo, Japan) and a manual back pressure regulator LF-540 from Pressure Tech (Hadfield, United Kingdom). Three factors were considered for the optimization of the SFE process: pressure (100-400 bar), temperature (40$\left.70^{\circ} \mathrm{C}\right)$ and the amount of ethanol $(0-50 \%)$ that was used as modifier. Optimization was 
Cite as:

Costa-Machado, A. R. M.; Freitas, L. A. P. de; Mendiola, J. A.; Ibáñez, Elena "Copaifera langsdorffii supercritical fluid extraction: Chemical and functional characterization by LC/MS and in vitro assays" Journal of Supercritical Fluids 100: 86-96 (2015) http://dx.doi.org/10.1016/j.supflu.2015.02.028

performed using a Box-Behnken experimental design. Experiments were carried out in randomized order. A kinetic study of the extraction process at the central conditions of the experimental design was carried out to select the extraction time that was set at $120 \mathrm{~min}$. The other factors were maintained constant: carbon dioxide flow rate, $1 \mathrm{~mL} / \mathrm{min}$ (measured at 50 bar)

150 and mass of plant, $1 \mathrm{~g}$.

Once obtained the optimized conditions according to the results of the Box-Behnken design and the statistical analysis, the scale up of the extraction conditions to obtain the extract enriched in kaurenoic acid was performed in a Helix Spe-ed SFE equipment (Applied Separations, Inc, Allentown, PA, USA) which was loaded with $50 \mathrm{~g}$ of $C$. langsdorffii dried and milled leaves.

155 The other conditions as pressure, temperature and modifier were selected as provided by the experimental design.

\subsection{Physico-chemical extract characterization}

\subsubsection{Yield $(\theta)$}

To obtain the soluble solids $(S S)$ extracted in the experiments, a thermogravimetric method was

160 used. For that, the liquid extracts were dried in an evaporator under vacuum and, after full dryness, they were weighted. These value were compared to the total mass of plant used $(M p)$ to obtain the yield [43].

$\theta=\frac{S S \times 100}{M p}$

\subsubsection{Total flavonoid quantification (TF)}

165 The method of complexation with aluminum chloride $\left(55.23 \mathrm{mg}\right.$ of $\mathrm{AlCl}_{3}$ anhydrous in $5 \mathrm{~mL}$ followed by a dilution of 10 fold) in methanol was applied to quantify the total flavonoid content using quercetin as standard $(4,6,8,10,12$ and $14 \mu \mathrm{g} / \mathrm{mL})$. The samples were diluted in methanol to obtain a concentration of total flavonoid of approximately $8 \mu \mathrm{g} / \mathrm{mL}$ or $0.5 \mathrm{mg} / \mathrm{mL}$ of dried 
Cite as:

Costa-Machado, A. R. M.; Freitas, L. A. P. de; Mendiola, J. A.; Ibáñez, Elena "Copaifera langsdorffii supercritical fluid extraction: Chemical and functional characterization by LC/MS and in vitro assays" Journal of Supercritical Fluids 100: 86-96 (2015) http://dx.doi.org/10.1016/j.supflu.2015.02.028

extract (330 fold dilution). A final concentration of $1.6 \mathrm{mM}$ of aluminum chloride in the reaction

170 media was obtained. The samples were analyzed at the wavelength of $425 \mathrm{~nm}$ in a micro plate reader, model Synergy HT (Biotek, Winooski, USA). The total flavonoids yield was calculated as milligrams per gram of soluble solids. The analyses were performed in triplicate $[44,45]$.

\subsubsection{Chromatographic method development and validation}

The kaurenoic acid and quercitrin quantifications were done by high performance liquid

175 chromatography (HPLC). The chromatographic analyses were carried out using an Agilent Liquid Chromatograph equipped with a DAD model G1315B Agilent 1100 series and an ALS injector G1329A Agilent 1200 series. The optimized chromatographic conditions allowing the elution and complete resolution of the compounds of interested consisted of a ACE C18-AR column $(150 \mathrm{~mm} \times 4.6 \mathrm{~mm}$, d.p. $3 \mu \mathrm{m}$, Advanced Chromatography Technologies Ltd, Aberdeen,

180 UK) using as mobile phases purified acetonitrile (A) and water (B) eluted according to the following gradient: $0 \mathrm{~min}, 90 \% \mathrm{~B} ; 5 \mathrm{~min}, 80 \% \mathrm{~B} ; 10 \mathrm{~min}, 65 \% \mathrm{~B} ; 15 \mathrm{~min}, 55 \% \mathrm{~B} ; 20 \mathrm{~min}, 0 \%$ B; $30 \mathrm{~min}, 0 \% \mathrm{~B} ; 35 \mathrm{~min}, 90 \% \mathrm{~B}$. The optimum flow rate was $0.8 \mathrm{~mL} / \mathrm{min}$ and the injection volume was $20 \mu \mathrm{L}$. The diode array detector recorded the spectra from 200 to $700 \mathrm{~nm}$. The compounds quercitrin (Q) and kaurenoic acid (KA) were quantified at $210 \mathrm{~nm}$. The kaurenoic acid and quercitrin concentrations were expressed as milligrams per $100 \mathrm{~g}$ of soluble solids. The method was validated regarding the selectivity, linearity, precision, accuracy, limit of detection and quantification.

To quantify kaurenoic acid and quercitrin, the solids of each extract were dissolved in $10 \mathrm{~mL}$ and then an aliquot of $50 \mu \mathrm{L}$ of this solution were diluted in $950 \mu \mathrm{L}$ of methanol. As the extracts 190 obtained in the runs 5, 6, 9 and 10 of the Box-Benhken design presented low values of solids as well as total flavonoids, they were diluted in $0.5 \mathrm{~mL}$ and then an aliquot of $50 \mu \mathrm{L}$ was diluted in 
Cite as:

Costa-Machado, A. R. M.; Freitas, L. A. P. de; Mendiola, J. A.; Ibáñez, Elena "Copaifera langsdorffii supercritical fluid extraction: Chemical and functional characterization by LC/MS and in vitro assays" Journal of Supercritical Fluids 100: 86-96 (2015) http://dx.doi.org/10.1016/j.supflu.2015.02.028

$950 \mu \mathrm{L}$ of methanol, as was performed to dilute the standards, to allow the quantification of the compounds in the developed method.

\subsubsection{LC/MS analysis}

195 The optimized extracts were qualitative analyzed in a LC/MS-ESI Accela composed of a photodiode array detector, an autosampler, a quaternary pump and a TSQ quantum access (Thermo, San Jose, USA). The column used was the ACE C18-AR column $(150 \mathrm{~mm} \times 4.6 \mathrm{~mm}$, d.p. $3 \mu \mathrm{m}$ ) using as mobile phases purified methanol (A) and water acidified with $0.2 \% \mathrm{v} / \mathrm{v}$ of formic acid (B) eluted according to the following gradient: $0 \mathrm{~min}, 25 \% \mathrm{~A} ; 25 \mathrm{~min}, 55 \% \mathrm{~A} ; 30$

$200 \mathrm{~min}, 100 \% \mathrm{~A} ; 35 \mathrm{~min}, 100 \% \mathrm{~A} ; 40 \mathrm{~min}, 25 \% \mathrm{~A} ; 45 \mathrm{~min}, 25 \% \mathrm{~A} ; 50 \mathrm{~min}, 100 \% \mathrm{~A}$. The flow rate was $0.6 \mathrm{~mL} / \mathrm{min}$ and the injection volume was $20 \mu \mathrm{L}$. The electrospray ionization (ESI) conditions were: capillary voltage: $3500 \mathrm{~V}$, end plate: $500 \mathrm{~V}$, capillary exit: $120 \mathrm{~V}$. Dependent scan types were obtained using skimmer offset of $6 \mathrm{~V}$ as first event and the peaks that presented signal threshold higher than $8.10^{5}$ counts received collision energy of $20 \mathrm{~V}$.

\subsubsection{Antioxidant activity}

\subsubsection{DPPH $\left(E C_{50}\right)$}

The DPPH scavenging activity was evaluated according to [44, 45]. Five concentrations of each sample were prepared. A volume of $25 \mu \mathrm{L}$ of the sample was added to $975 \mu \mathrm{L}$ of the $60 \mu \mathrm{M}$ DPPH solution. These solutions were maintained in reaction during 30 minutes in the dark. The

210 DPPH scavenging activity was measured at $516 \mathrm{~nm}$ in a micro plate reader, model Synergy HT (Biotek, Winooski, USA). The percentage of DPPH scavenging activity was calculated as shown in equation 2. The concentration corresponding to $50 \%$ of $\mathrm{DPPH}$ inhibition $\left(\mathrm{EC}_{50}\right)$ was determined by fitting a linear model to the calibration curve $(7.5,15,30,45,60$ and $90 \mathrm{mM})$. The $\mathrm{EC}_{50}$ of the samples were compared with $\mathrm{EC}_{50}$ of quercetin and $\mathrm{BHT}$. The analyses were performed in triplicate. 
Cite as:

Costa-Machado, A. R. M.; Freitas, L. A. P. de; Mendiola, J. A.; Ibáñez, Elena "Copaifera langsdorffii supercritical fluid extraction: Chemical and functional characterization by LC/MS and in vitro assays" Journal of Supercritical Fluids 100: 86-96 (2015) http://dx.doi.org/10.1016/j.supflu.2015.02.028

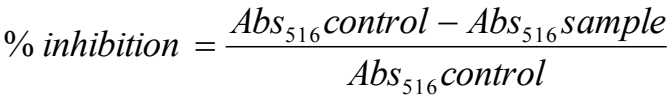

\subsubsection{TEAC}

The TEAC assay was performed according to [46]. The ABTS radical cation $\left(\mathrm{ABTS}^{\bullet+}\right)$ was produced by adding $7 \mathrm{mM}$ ABTS with $2.45 \mathrm{mM}$ potassium persulfate allowing to react in the dark at room temperature for $12-16 \mathrm{~h}$ before use. The aqueous $\mathrm{ABTS}^{\circ+}$ solution was diluted with $5 \mathrm{mM}$ phosphate buffer $(\mathrm{pH}=7.4)$ to an absorbance of $0.70( \pm 0.02)$ at $734 \mathrm{~nm}$. Ten microliters of sample (different concentrations) was added to $1 \mathrm{~mL}$ of diluted ABTS ${ }^{\circ+}$ radical solution. After 50 min at $30^{\circ} \mathrm{C}, 300 \mu \mathrm{L}$ of the mixture was transferred into a well of the microplate and the absorbance was measured at $734 \mathrm{~nm}$ in a microplate spectrophotometer reader (Synergy HT,

BioTek Instruments). Trolox was used as reference standard and results were expressed as TEAC values (mmol Trolox/g extract). These values were obtained from at least four different concentrations of each extract tested in the assay giving a linear response between 20 and $80 \%$ of the blank absorbance. All analyses were performed in triplicate.

\subsubsection{Statistical analysis}

230 The Box-Behnken design results were analyzed by ANOVA regarding $\mathrm{p}<0.5$ as significant and response surface were plotted to help to evaluate the results. For that, the statistical software Statistica ${ }^{\circledR} 11.0$ version and MiniTab ${ }^{\circledR} 7.0$ version were used. One-sample statistical analyses were evaluated by t-test in the GraphPad Prism 5.03 version software.

\section{Results and Discussion}

\subsection{Chromatographic method development}

A chromatographic method was developed in order to quantify the kaurenoic acid and quercitrin in the $C$. langsdorffi extracts. After developing the method, it was validated regarding its selectivity, linearity, accuracy, precision, limit of detection and quantification [47]. 
Cite as:

Costa-Machado, A. R. M.; Freitas, L. A. P. de; Mendiola, J. A.; Ibáñez, Elena "Copaifera langsdorffii supercritical fluid extraction: Chemical and functional characterization by LC/MS and in vitro assays" Journal of Supercritical Fluids 100: 86-96 (2015) http://dx.doi.org/10.1016/j.supflu.2015.02.028

In order to evaluate the selectivity of the method towards the separation of quercitrin and

240 kaurenoic acid, the SLE extract, that presented the most complex profile, was injected and compared with the standards and the blank (solvent). Furthermore, the UV-vis spectra were evaluated to corroborate that no co-elution was observed under the optimized separation conditions. Quercetrin eluted at $11.095 \mathrm{~min}$ and kaurenoic acid at $23.625 \mathrm{~min}$; quercitrin spectrum showed two characteristic maximum wavelengths at 255 and $349 \mathrm{~nm}$ while kaurenoic acid spectrum showed a maximum at $210 \mathrm{~nm}$. No interferences were observed with the rest of compounds eluted in the chromatogram. Figures of merit of the developed HPLC method for quantification of kaurenoic acid and quercitrin are shown in Table 1.

\subsection{Solid-liquid extraction (SLE)}

The extraction yield, total flavonoids, antioxidant activity and kaurenoic acid and quercitrin 250 concentration of the extracts obtained by SLE are presented in Table 2. The yields obtained, around $32.12 \pm 0.93 \% \mathrm{w} / \mathrm{w}$, are in accordance with values achieved previously in our laboratory by SLE and Soxhlet (SOX) extraction using ethanol as solvent [49]. Also, the total flavonoids of the C. langsdorffii extract obtained by an optimized SLE condition presented $10.2 \pm 0.25 \mathrm{mg} / \mathrm{g}$ and quercitrin of $7.70 \pm 0.02 \mathrm{mg} / \mathrm{g}$, both values lower than the SLE values observed in this study

255 [49]. These results may vary because of the plant variability in its secondary compounds' metabolism is influenced by solar irradiation and/or the amount of raining in the season [50].

\subsection{Supercritical Fluid Extraction}

\subsubsection{Kinetics}

Initially, the kinetics of the supercritical fluid extraction process was evaluated considering 250

260 bar and $55^{\circ} \mathrm{C}$ (central point of the experimental design) to find a suitable extraction time. There is an increasing extraction rate until 80 minutes (constant extraction rate, CER), followed by a 
Cite as:

Costa-Machado, A. R. M.; Freitas, L. A. P. de; Mendiola, J. A.; Ibáñez, Elena "Copaifera langsdorffii supercritical fluid extraction: Chemical and functional characterization by LC/MS and in vitro assays" Journal of Supercritical Fluids 100: 86-96 (2015) http://dx.doi.org/10.1016/j.supflu.2015.02.028

period of falling extraction rate of about $40 \mathrm{~min}$; after that, there is no significant increase in the amount of soluble solids extracted. Thus, 120 minutes was selected as the extraction time.

\subsubsection{Box-Behnken optimization of SFE}

265 As mentioned, a Box-Behnken experimental design was used to optimize the SFE process. The matrix of the design, together with the results of the different studied responses, are presented in Table 3. It is worth to mention that the variability of the process, studied at the central point (experiments 13, 14 and 15), was below $10 \%$ for all the responses.

As can be seen, total flavonoids are not always proportional to the yield values. For instance, in run 3 , the highest yield was obtained $(14.5 \% \mathrm{w} / \mathrm{w})$ corresponding to a medium value of flavonoids content $(50.9 \mathrm{mg} / \mathrm{g})$ while run 2 provided a medium yield $(7.0 \% \mathrm{w} / \mathrm{w})$ and the highest content in flavonoids $(76.6 \mathrm{mg} / \mathrm{g})$. This, in fact, demonstrates the selectivity of the process towards the extraction of selected target compounds such as flavonoids.

Comparing the results of the SFE and SLE, it can be observed that SLE presented approximately 3-fold higher yield values and around 10-fold less total flavonoids than the extracts obtained by SFE, thus showing the selectivity associated to the extraction of flavonoids under supercritical conditions. As for kaurenoic acid content, it can be seen that SFE is able to extract 10 -fold more than SLE, being a better extraction method than SLE to extract non-polar compounds using nontoxic solvents such as $\mathrm{CO}_{2}$.

280 Comparing SFE and SLE in terms of antioxidant activity, it can be observed that both presented similar $\mathrm{EC}_{50}$ values, thus corroborating the fact that the antioxidant activity is not strictly related to the flavonoids content. For instance, the best DPPH antioxidant activity (run $11,7.581 \mu \mathrm{g} / \mathrm{mL}$ ) was neither related with the highest yield nor with the highest total flavonoid content; thus, the antioxidant activity can be due to the presence of several compounds other than flavonoids, 285 belonging or not to the polyphenolic group [51, 52]. Values obtained for DPPH in the present 
Cite as:

Costa-Machado, A. R. M.; Freitas, L. A. P. de; Mendiola, J. A.; Ibáñez, Elena "Copaifera langsdorffii supercritical fluid extraction: Chemical and functional characterization by LC/MS and in vitro assays" Journal of Supercritical Fluids 100: 86-96 (2015) http://dx.doi.org/10.1016/j.supflu.2015.02.028

work were similar to those reported for supercritical extracts of other plants such as Rosmarinus

officinalis [53] or Solanum paludosum [54]. Compared to the antioxidant activity of quercetin (standard) and BHT ( $\mathrm{EC}_{50}$ values equal to 1.94 and $48.46 \mu \mathrm{g} / \mathrm{mL}$, respectively), it can be concluded that $C$. langsdorffii extracts have a strong antioxidant activity.

290 As for the antioxidant activity measured by using the TEAC method, a positive correlation was observed between the TEAC values and the total flavonoids content in the central point of the Box-Behnken design. Runs 13, 14 and 15, which presented the best TEAC values (2.261, 2.111 and $2.123 \mathrm{mmol} / \mathrm{g}$, respectively) also presented the highest values of total flavonoids (66.635, 68.293 and $72.921 \mathrm{mg} / \mathrm{g}$, respectively). However, this correlation was different for the SLE extracts where the values of total flavonoids were 3 -fold lower than in the central points of the SFE Box-Behnken design and the TEAC values were similar. Once more, it is possible to notice that the antioxidant activity is not strictly dependent of the flavonoids, and probably other antioxidant compounds are also extracted but not quantified by the methods employed.

\subsubsection{Statistical analysis}

300 As mentioned, 3 factors were selected to optimize the extraction of bioactive compounds of $C$. langsdorffii using SFE: extraction pressure, extraction temperature and ethanol percentage. After performing the ANOVA for each of the responses (data not shown) the model was fitted; Table 4 shows the regression coefficients for the different factors and the statistics for goodness of fit of the models for all the response variables. As a general trend, it can be observed that ethanol significantly influenced all the responses (except kaurenoic acid) in its linear and quadratic form. This means that the yield, total flavonoids, quercitrin and antioxidant activity (evaluated by both, DPPH and TEAC) are maximum when ethanol is at its highest level (50\%) and they decrease if the ethanol concentration increases or decreases (see Figures 2 A, B, D, E and F). On the other hand, for kaurenoic acid, ethanol was significant only in its linear form and its coefficient was 
Cite as:

Costa-Machado, A. R. M.; Freitas, L. A. P. de; Mendiola, J. A.; Ibáñez, Elena "Copaifera langsdorffii supercritical fluid extraction: Chemical and functional characterization by LC/MS and in vitro assays" Journal of Supercritical Fluids 100: 86-96 (2015) http://dx.doi.org/10.1016/j.supflu.2015.02.028

negative, meaning that the kaurenoic acid values are the highest when ethanol percentage is the

lowest (see Figure 2C). This is in agreement with the reported solubility of kaurenoic acid, which is maximum in non-polar solvents [23]. Moreover, considering extraction yield, temperature was also a significant factor in its linear form $(p=0.034)$; so, yields can be the highest when the temperature is equal to or above $70^{\circ} \mathrm{C}$ (see Figure $2 \mathrm{~A}$ ).

315 As can be observed in Figures $2 \mathrm{C}$ and 2D, the maximum extraction of kaurenoic acid and quercitrin are obtained under completely different percentages of ethanol which, in fact, was the main factor influencing their extraction under supercritical fluids conditions. In this sense, when using high percentages of ethanol as modifier, extracts preferentially enriched in quercitrin were obtained while kaurenoic acid was barely extracted. As mentioned, this is in agreement with the 320 different solubility reported for both types of compounds.

As for the antioxidant activity, measured using the DPPH in vitro assay, the ANOVA also presented the interaction between the temperature and ethanol as significant; that means that ethanol percentage must be around $50 \%$ (high) and temperature has to be low $\left(<40^{\circ} \mathrm{C}\right)$ to provide the lowest values of $\mathrm{EC}_{50}$. For the response related to the antioxidant activity measured using 325 TEAC in vitro assay, the ANOVA also presented as significant the quadratic effect of the pressure and temperature, besides the effect of the ethanol. This means that the TEAC values are the highest when the ethanol is around $50 \%$, the pressure 250 bar and the temperature $55^{\circ} \mathrm{C}$. In the response surface (Figure $2 \mathrm{~F}$ ) it is possible to observe exactly the stationary point of maximum TEAC value.

330 It has to be pointed out that, in general, the correlation coefficient $\left(\mathrm{R}^{2}\right)$ and the adjusted correlation coefficient $\left(\mathrm{R}_{\text {adj }}^{2}\right)$ of the models presented very similar values thus indicating a good fit; only for the kaurenoic acid, these coefficients presented values far from each other $(0.829$ and 0.521 , respectively) pointing out that the estimative values of the model, including the 
Cite as:

Costa-Machado, A. R. M.; Freitas, L. A. P. de; Mendiola, J. A.; Ibáñez, Elena "Copaifera langsdorffii supercritical fluid extraction: Chemical and functional characterization by LC/MS and in vitro assays" Journal of Supercritical Fluids 100: 86-96 (2015) http://dx.doi.org/10.1016/j.supflu.2015.02.028

optimized predicted values, will not be so precise since other factors different from those

335 considered in the optimization may have an influence in the final response.

\subsubsection{Supercritical fluid extraction conditions optimization}

From the results obtained it was possible to observe that not all the studied responses could be optimized at the same time. Therefore, two different features set to the extracts were selected for optimization: 1) maximize yield, total flavonoids content and quercitrin concentration and 340 minimize $\mathrm{EC}_{50}$ (DPPH assay), this extract will be called High Quercetrin Extract (HQE); 2) maximize kaurenoic acid concentration, this extract will be called High Kaurenoic Acid Extract (HKAE). The TEAC antioxidant activity was neglected because it decreased the optimum extraction conditions, the desirability function as well as the estimative responses of the other responses.

345 Table 5 shows the goals, experimental conditions and response values (predicted and experimental) for HQE considering the optimum extraction conditions: pressure, 100 bar; temperature, $70^{\circ} \mathrm{C}$ and a percentage of ethanol as modifier, $50 \%$. As can be seen, there was no statistically difference $(\alpha=0.05$ on t-Student test) between the predicted and real values for the responses. By this way, the proposed model studied in this work can be considered validated and

350 appropriate to estimate these responses.

In parallel, the model provided by the Box-Behnken design was used to reach the conditions in order to obtain the HKAE. The provided values of the desired responses are presented in Table 6, together with the real values obtained experimentally. The optimum extraction conditions provided by the model to maximize kaurenoic acid content in the extract were as follows: pressure, 390 bar; temperature, $70^{\circ} \mathrm{C}$ and pure $\mathrm{CO}_{2}$. The predicted response for the kaurenoic acid value was $198.68 \mathrm{mg} / \mathrm{g}$ and the desirability was 0.870 . The extraction was performed at optimum conditions by triplicate; the analysis of the extracts resulted in a kaurenoic acid 
Cite as:

Costa-Machado, A. R. M.; Freitas, L. A. P. de; Mendiola, J. A.; Ibáñez, Elena "Copaifera langsdorffii supercritical fluid extraction: Chemical and functional characterization by LC/MS and in vitro assays" Journal of Supercritical Fluids 100: 86-96 (2015) http://dx.doi.org/10.1016/j.supflu.2015.02.028

concentration of $262.92 \pm 14.28 \mathrm{mg} / \mathrm{g}$. This value was statistically different ( $\alpha=0.05$ on t-test with

a Welch's correction) from the value provided by the software of $198.68 \mathrm{mg} / \mathrm{g}$. This result can be due to the fact the correlation coefficient $(0.829)$ and the adjusted correlation coefficient values were far from each other $(0.520)$ which means it was expected that the estimative values in the model could vary from the real values.

\subsection{Scale up extraction}

Once obtained the optimized conditions, the scale up of the extraction in order to obtain the

365 extract enriched in kaurenoic acid was performed allowing a scale up of 50-fold. The conditions as pressure, temperature and ethanol percentage were selected as provided by the experimental design.

The result for the kaurenoic acid values in the scaled-up extracts was of $266.39 \pm 14.96 \mathrm{mg} / \mathrm{g}$. This value is similar to the result of the real kaurenoic acid content in the optimized extract obtained in the bench scale $(262.92 \pm 14.28 \mathrm{mg} / \mathrm{g})$. The results of yields were also similar in both scales, $1.00 \pm 0.20 \% \mathrm{w} / \mathrm{w}$ for the bench supercritical fluid equipment and $1.87 \pm 0.54 \% \mathrm{w} / \mathrm{w}$ for the scaled-up equipment. Observing these two results, it is possible to infer the scale up of the SFE was successful making possible to amplify the extraction 50-fold.

\subsection{LC/MS analysis}

375 The $C$. langsdorffii optimized extracts were analyzed by using HPLC coupled to MS-ESI in negative ionization mode in order to carry out a qualitative characterization of bioactive phenolic compounds in $C$. langsdorffii leaves. The peaks of the chromatogram that presented signal threshold higher than $8.10^{5}$ counts received collision energy of $20 \mathrm{~V}$ in order to fragment the compound and make possible to evaluate its fragmentation profile. So, the peak identification 
Cite as:

Costa-Machado, A. R. M.; Freitas, L. A. P. de; Mendiola, J. A.; Ibáñez, Elena "Copaifera langsdorffii supercritical fluid extraction: Chemical and functional characterization by LC/MS and in vitro assays" Journal of Supercritical Fluids 100: 86-96 (2015) http://dx.doi.org/10.1016/j.supflu.2015.02.028

mass spectrum obtained by MS-ESI, the fragmentation profile and previous reports in the literature related to the genus Copaifera or to the family Fabaceae $[13,22,55,56]$.

The profile of the extract with high values of quercitrin (HQE) showed several peaks corresponding to acidic diterpene, polyphenols and polar compounds among which 21 were

tentatively characterized. The compounds are reported in Table $\mathbf{6}$ presenting their retention time, molecular weight (MW), experimental $\mathrm{m} / \mathrm{z}^{-}$, maximum $\mathrm{UV}$-visible bands $\left(\lambda_{\max }\right)$, proposed fragment and proposed tentative identification.

Although in the literature several researches concerning the analysis of the oil obtained from the trunk of Copaifera trees have been described, few works can be found identifying compounds 390 from the leaves of Copaifera, specially the phenolic and polar compounds. Therefore, to identify the major compounds of the extracts obtained from $C$. langsdorffii leaves'extracts by using HPLC coupled to diode array and mass spectrometry detectors can be considered an important contribution.

As mentioned, researches performed of C. langsdorffii leaves in the 1980's reported that they present from 6 to $10 \%$ of phenolic compounds, $3 \%$ of the amino acid N-metyl-trans-4-hidroxi-Lproline and sesquiterpenes ( $\alpha$-cubebene, $\alpha$-copaene, ciperene, $\beta$-copaene, caryophyllene, $\beta$ humulene, muurolene, $\beta$-selinene, $\delta$-cadinene and $\gamma$-cadinene, caryophyllene oxide) [10-12]. Furthermore, recent works reported that their leaves present acidic diterpenes (kaurenoic acid, hydroxy-labdanolic acid), alcoholic diterpenes (kaurenol) and flavonoids (quecitrin and afzelin) 400 [13]. In a more recent study [22], 26 galloylquinic acids, some of them methylated, were identified as polar compounds presented in the C. langsdorffii leaves.

In the present study, we observed that the extracts obtained under optimum conditions employing $50 \%$ of ethanol as modifier, that is, those extracts containing the highest 405 concentration of polar compounds, presented good results of antioxidant activity (using both, 
Cite as:

Costa-Machado, A. R. M.; Freitas, L. A. P. de; Mendiola, J. A.; Ibáñez, Elena "Copaifera langsdorffii supercritical fluid extraction: Chemical and functional characterization by LC/MS and in vitro assays" Journal of Supercritical Fluids 100: 86-96 (2015) http://dx.doi.org/10.1016/j.supflu.2015.02.028

DPPH and TEAC methods). These results suggest that the described galloylquinic acids, together with the flavonoids, can be the main responsible for the antioxidant activity of the $C$. langsdorffii leaves' extracts. Meanwhile, the SFE extracts using pure carbon dioxide did not presented any detectable antioxidant activity.

410 Quercitrin standard presented a retention time of $21 \mathrm{~min}$, a molecular weight of $447^{-} \mathrm{m} / \mathrm{z}$ [M-H] and a UV-vis spectrum with maximum wavelength of 256 and $348 \mathrm{~nm}$ (Figure 3). Its fragmentation profile provided a mass of $301^{-} \mathrm{m} / \mathrm{z}$ which corresponds to the loss of the glycoside providing the quercetin.

Flavonoids represent a subgroup of phenolic phytochemicals [57] and quercitrin is one

415 representative. It is reported to be an oxidative stress protector, which normalized the intestinal oxidative status in rats after oral administration [58]. Other flavonoid found in the HQE was afzelin that is the glycosylated form of kaempferol, a flavonol. Afzelin was reported to be able to inhibit intestinal absorption of glucose what can be an interesting use as a nutraceutical product [59].

420 As could be observed, kaurenoic acid, a diterpenic acid, was also present in the HQE and HKAE. The kaurenoic acid standard was analyzed and presented a retention time of 35.8 min, a molecular weight of $301^{-} \mathrm{m} / \mathrm{z}[\mathrm{M}-\mathrm{H}]$ and UV-vis spectrum with no maximum wavelength, as expected since it does not present double bonds.

Kaurenoic acid has been reported to possess several biological activities such as: antimicrobial, 425 antifungal [24], anti-inflammatory [25], vasodilator [26], wound healing [27], anti-psoriasis [28], trypanocide, cytotoxic, potent stimulators of uterine contraction $[60,61]$ and antitumor activity [29-35]. Besides, the kaurenoic acid has been used in semi-synthesis as a precursor to obtain more selective and/or more bioactive derivative as, for example, to enhance tripanomicidal actitivy [61] and even to obtain compounds with enhanced antiplasmodial activity [60]. 
Cite as:

Costa-Machado, A. R. M.; Freitas, L. A. P. de; Mendiola, J. A.; Ibáñez, Elena "Copaifera langsdorffii supercritical fluid extraction: Chemical and functional characterization by LC/MS and in vitro assays" Journal of Supercritical Fluids 100: 86-96 (2015) http://dx.doi.org/10.1016/j.supflu.2015.02.028

430 Galloylquinic acids were widely found in the HQE; several of them are isomers since they are present in the methylated form and the methyl group can vary its position as can be observed in Figure 3. Various galloyl derivatives of quinic acid were found to be inhibitors of human DNA polymerases. Among them, 3,4,5-tri-O-galloylquinic acid was the most potent inhibitor of DNA polymerase $\alpha[62]$.

435 The LC/MS analysis of the HKAE (optimum conditions: 390 bar; temperature, $70^{\circ} \mathrm{C}$ and pure $\mathrm{CO}_{2}$ ) was also performed. As expected, these conditions favored the extraction of non-polar compounds from the leaves of C. langsdorffii.

\section{Conclusion}

440 In conclusion, temperature and ethanol percentage were the factors that mostly influenced the SFE of the chemical compounds from $C$. langsdorffii leaves. Besides, the use of response surface methodology allowed the modulation of the composition of the extract providing extracts enriched in either quercitrin or kaurenoic acid. A high content of kaurenoic acid (HKAE) could be obtained at 390 bar, $70^{\circ} \mathrm{C}$ of temperature and pure $\mathrm{CO}_{2}$, while an extract rich in phenolic

445 compounds can be obtained at 100 bar, $55^{\circ} \mathrm{C}$ and using $50 \%$ ethanol as modifier (HQE). The qualitative LC/MS analysis allowed the tentative identification of galloylquinic acids in the HQE optimized extracts; those compounds were not present in the HKAE extracts, as expected. SFE was an efficient method for the extraction of bioactive compounds from C. langsdorffii leaves while avoiding the use of toxic organic solvents that could be later on found in the product or delivered it to the environment.

\section{Acknowledgements}

The authors are grateful to FAPESP (Fundação de Amparo à Pesquisa do Estado de São Paulo) for the financial support. 
Cite as:

Costa-Machado, A. R. M.; Freitas, L. A. P. de; Mendiola, J. A.; Ibáñez, Elena "Copaifera langsdorffii supercritical fluid extraction: Chemical and functional characterization by LC/MS and in vitro assays" Journal of Supercritical Fluids 100: 86-96 (2015) http://dx.doi.org/10.1016/j.supflu.2015.02.028

\section{References}

455 [1] V.F. Veiga, A.C. Pinto, The Copaifera L. genus., Quim Nova, 25 (2002) 273-286.

[2] V.F. Veiga, A.C. Pinto, M.A.M. Maciel, Medicinal plants: safe cure?, Quim Nova, 28 (2005) 519-528.

[3] V. Cascon, Copaíba - Copaifera spp., in: J.C.T. Carvalho (Ed.) Fitoterápicos antiinflamatórios: aspectos químicos, farmacológicos e aplicações terapêuticas, Tecmedd, Ribeirão Preto, 2004, pp. 221-256,.

[4] L.A.F. Paiva, L.A. Gurgel, E.T. De Sousa, E.R. Silveira, R.M. Silva, F.A. Santos, V.S.N. Rao, Protective effect of Copaifera langsdorffii oleo-resin against acetic acid-induced colitis in rats, Journal of Ethnopharmacology, 93 (2004) 51-56.

[5] L.A.F. Paiva, L.A. Gurgel, R.M. Silva, A.R. Tome, N.V. Gramosa, E.R. Silveira, F.A.

465 Santos, V.S.N. Rao, Anti-inflammatory effect of kaurenoic acid, a diterpene from Copaifera langsdorffii on acetic acid-induced colitis in rats, Vascular Pharmacology, 39 (2002) 303-307.

[6] J.P.B. Sousa, N.P.D. Nanayakkara, A.A. Berretta, J.K. Bastos, Leishmanicidal and antimalarial activities of crude extracts from aerial parts of Copaifera langsdorffii and isolation of secondary metabolites, Journal of Pharmacy Research, 5 (2012) 4103-4107.

470 [7] J.K. Bastos, A.R.F. Brunharoto, C. Brunharoto-Júnior, L.P.F. Brunharoto, Process of obtation and uses of the extracts, fractions and isolated substances from Copaifera species in the treatement of urinary lithiasis in human beings and animals, in: Instituto Nacional de Propriedade Intelectual, Brasil, 2005.

[8] R.B. de Oliveira, E.B. Coelho, M.R. Rodrigues, A.R.M. Costa-Machado, J.P.B. de Sousa, 475 A.A. Berretta, J.K. Bastos, Effect of the Copaifera langsdorffii Desf. Leaf Extract on the Ethylene Glycol-Induced Nephrolithiasis in Rats, Evidence-Based Complementary and Alternative Medicine, (2013) doi.org/10.1155/2013/131372.

[9] A.P.S. Brancalion, R.B. Oliveira, J.P.B. Sousa, M. Groppo, A.A. Berretta, M.E. Barros, M.A. Boim, J.K. Bastos, Effect of hydroalcoholic extract from Copaifera langsdorffii leaves on 480 urolithiasis induced in rats, Urological Research, 40 (2012) 475-481.

[10] J.H. Langenheim, C.L. Convis, C.A. Macedo, W.H. Stubblebine, Hymenaea and Copaifera leaf sesquiterpenes in relation to lepidopteran herbivory in southeastern Brazil, Biochemical Systematics and Ecology, 14 (1986) 41-49.

[11] C.A. Macedo, J.H. Langenheim, A further investigation of leaf sesquiterpene variation in 485 relation to herbivory in 2 Brazilian populations of Copaifera langsdorfii, Biochemical Systematics and Ecology, 17 (1989) 207-216.

[12] C.A. Macedo, J.H. Langenheim, Microlepidopteran herbivory in relation to leaf sesquiterpenes in Copaifera langsdorfii adult trees and their seedling progeny in a Brazilian woodland, Biochemical Systematics and Ecology, 17 (1989) 217-224.

490 [13] J.P.B. Sousa, A.P.S. Brancalion, M.G. Junior, J.K. Bastos, A validated chromatographic method for the determination of flavonoids in Copaifera langsdorffii by HPLC, Natural Product Communications, 7 (2012) 25-29.

[14] Quercitrin, National Center for Biotechnology Information, PubChem Compound Database, Accessed in 19 November 2014. Available from:

495 http://pubchem.ncbi.nlm.nih.gov/summary/summary.cgi?sid=87225407

[15] S. Kim, H. Kim, S. Choi, K. Park, H. Choi, M. Lee, Anti-oxidative and inhibitory activities on nitric oxide (NO) and prostaglandin E2 (COX-2) production of flavonoids from seeds of Prunus tomentosa Thunberg, Archives of Pharmacal Research, 31 (2008) 424-428. 
Cite as:

Costa-Machado, A. R. M.; Freitas, L. A. P. de; Mendiola, J. A.; Ibáñez, Elena "Copaifera langsdorffii supercritical fluid extraction: Chemical and functional characterization by LC/MS and in vitro assays" Journal of Supercritical Fluids 100: 86-96 (2015) http://dx.doi.org/10.1016/j.supflu.2015.02.028

[16] G.H. Xu, I.J. Ryoo, Y.H. Kim, S.J. Choo, I.D. Yoo, Free radical scavenging and antielastase activities of flavonoids from the fruits of Thuja orientalis, Archives of Pharmacal Research, 32 (2009) 275-282.

[17] W. Li, D.K.J. Lin, Optimal foldover plans for two-level fractional factorial designs, Technometrics, 45 (2003) 142-149.

[18] B.S. Min, S.Y. Lee, J.H. Kim, J.K. Lee, T.J. Kim, D.H. Kim, Y.H. Kim, H. Joung, H.K.

Lee, N. Nakamura, H. Miyashiro, M. Hattori, Anti-complement activity of constituents from the stem-bark of Juglans mandshurica, Biological \& Pharmaceutical Bulletin, 26 (2003) 1042-1044.

[19] E.K. Kwon, D.Y. Lee, H. Lee, D.O. Kim, N.I. Baek, Y.E. Kim, H.Y. Kim, Flavonoids from the buds of Rosa damascena inhibit the activity of 3-Hydroxy-3-methylglutaryl-coenzyme a reductase and angiotensin I-converting enzyme, Journal of Agricultural and Food Chemistry, 58

$510 \quad$ (2010) 882-886.

[20] H.S. Rho, S.M. Ahn, B.C. Lee, M.K. Kim, A.K. Ghimeray, C.W. Jin, D.H. Cho, Changes in flavonoid content and tyrosinase inhibitory activity in kenaf leaf extract after far-infrared treatment, Bioorganic \& Medicinal Chemistry Letters, 20 (2010) 7534-7536.

[21] L.O. Regasini, J.C.R. Vellosa, D.H.S. Silva, M. Furlan, O.M.M. Oliveira, N.M. Khalil, I.L.

515 Brunetti, M.C.M. Young, E.J. Barreiro, V.S. Bolzani, Flavonols from Pterogyne nitens and their evaluation as myeloperoxidase inhibitors, Phytochemistry, 69 (2008) 1739-1744.

[22] Motta, Desenvolvimento e validação de método analítico por CLAE-UV-DAD para quantificação e análise sazonal de derivados galoilquínicos nas folhas de Copaifera langsdorffii, in: Faculdade de Ciências Farmacêuticas de Ribeirão Preto, Universidade de São Paulo, Ribeirão 520 Preto, 2014, pp. 160.

[23] Kaurenoic, National Center for Biotechnology Information, PubChem Compound Database, Accessed in 19 November 2014. Available from: http://pubchem.ncbi.nlm.nih.gov/summary/summary.cgi?sid=14036

[24] E.P. Padla, L.T. Solis, C.Y. Ragasa, Antibacterial and antifungal properties of ent-kaurenoic acid from Smallanthus sonchifolius, Chinese Journal of Natural Medicines, 10 (2012) 408-414.

[25] R.J. Choi, E.M. Shin, H.A. Jung, J.S. Choi, Y.S. Kim, Inhibitory effects of kaurenoic acid from Aralia continentalis on LPS-induced inflammatory response in RAW264.7 macrophages, Phytomedicine, 18 (2011) 677-682.

[26] C.R. Tirapelli, S.R. Ambrosio, F.B. da Costa, S.T. Coutinho, D.C.R. de Oliveira, A.M. de

530 Oliveira, Analysis of the mechanisms underlying the vasorelaxant action of kaurenoic acid in the isolated rat aorta, European Journal of Pharmacology, 492 (2004) 233-241.

[27] N. Balekar, T. Nakpheng, N.G. Katkam, T. Srichana, Wound healing activity of ent-kaura9(11),16-dien-19-oic acid isolated from Wedelia trilobata (L.) leaves, Phytomedicine, 19 (2012) $1178-1184$.

535 [28] F. Gelmini, G. Beretta, C. Anselmi, M. Centini, P. Magni, M. Ruscica, A. Cavalchini, R.M. Facino, GC-MS profiling of the phytochemical constituents of the oleoresin from Copaifera langsdorffii Desf. and a preliminary in vivo evaluation of its antipsoriatic effect, European Journal of Pharmacology, 440 (2013) 170-178.

[29] B.C. Cavalcanti, D.P. Bezerra, H.I.F. Magalhães, M.O. Moraes, M.A.S. Lima, E.R. Silveira,

540 C.A.G. Câmara, V.S. Rao, C. Pessoa, L.V. Costa-Lotufo, Kauren-19-oic acid induces DNA damage followed by apoptosis in human leukemia cells, Journal of Applied Toxicology, 29 (2009) 560-568.

[30] L.V. Costa-Lotufo, G.M.A. Cunha, P.A.M. Farias, G.S.B. Viana, K.M.A. Cunha, C. Pessoa, M.O. Moraes, E.R. Silveira, N.V. Gramosa, V.S.N. Rao, The cytotoxic and embryotoxic effects 545 of kaurenoic acid, a diterpene isolated from Copaifera langsdorffii oleo-resin, Toxicon, 40 (2002) 1231-1234. 
Cite as:

Costa-Machado, A. R. M.; Freitas, L. A. P. de; Mendiola, J. A.; Ibáñez, Elena "Copaifera langsdorffii supercritical fluid extraction: Chemical and functional characterization by LC/MS and in vitro assays" Journal of Supercritical Fluids 100: 86-96 (2015) http://dx.doi.org/10.1016/j.supflu.2015.02.028

[31] N.d.M. Gomes, C.d.M. Rezende, S.P. Fontes, A.M.C. Hovell, R.G. Landgraf, M.E. Matheus, A.d.C. Pinto, P.D. Fernandes, Antineoplasic activity of Copaifera multijuga oil and fractions against ascitic and solid Ehrlich tumor, Journal of Ethnopharmacology, 119 (2008) $550 \quad 179-184$

[32] S.R.M. Lima, V.F. Veiga, H.B. Christo, A.C. Pinto, P.D. Fernandes, In vivo and in vitro studies on the anticancer activity of Copaifera multijuga Hayne and its fractions, Phytotherapy Research, 17 (2003) 1048-1053.

[33] M.O. Moraes, M.C. Fonteles, M.E.A. Moraes, M.I.L. Machado, F.J.A. Matos, Screening for anticancer activity of plants from the Northeast of Brazil, Fitoterapia, 68 (1997) 235.

[34] A. Ohsaki, L.T. Yan, S. Ito, H. Edatsugi, D. Iwata, Y. Komoda, The isolation and in-vivo potent antitumor-activity of clerodane diterpenoid from the oleoresin of the Brazilian medicinal plant, Copaifera-langsdorfii Desfon, Bioorganic \& Medicinal Chemistry Letters, 4 (1994) 28892892.

560 [35] C.D. Souza, J.M. Felfili, Uso de plantas medicinais na região de Alto Paraíso de Goiás, Acta Botanica Brasilica, 20 (2006) 7.

[36] M. Contini, S. Baccelloni, R. Massantini, G. Anelli, Extraction of natural antioxidants from hazelnut (Corylus avellana L.) shell and skin wastes by long maceration at room temperature, Food Chemistry, 110 (2008) 659-669.

565 [37] Brazilian Pharmacopoeia, in, ANVISA. Agência Nacional de Vigilância Sanitária. Fundação Oswaldo Cruz, Brasília, DF, 2010.

[38] M. Herrero, A. Cifuentes, E. Ibañez, Sub- and supercritical fluid extraction of functional ingredients from different natural sources: Plants, food-by-products, algae and microalgae: A review, Food Chemistry, 98 (2006) 136-148.

570 [39] T. Anaelle, E. Serrano Leon, V. Laurent, I. Elena, J.A. Mendiola, C. Stéphane, K. Nelly, L.B. Stéphane, M. Luc, S.-P. Valérie, Green improved processes to extract bioactive phenolic compounds from brown macroalgae using Sargassum muticum as model, Talanta, 104 (2013) 44-52.

[40] B. Beňová, M. Adam, P. Pavlíková, J. Fischer, Supercritical fluid extraction of piceid, resveratrol and emodin from Japanese knotweed, Journal of Supercritical Fluids, 51 (2010) 325330.

[41] J.H.Y. Vilegas, E. de Marchi, F.M. Lancas, Extraction of low-polarity compounds (with emphasis on coumarin and kaurenoic acid) from Mikania glomerata ('guaco') leaves, Phytochemical Analysis, 8 (1997) 266-270.

580 [42] E. Shortle, J. Kerry, A. Furey, D. Gilroy, Optimisation of process variables for antioxidant components from Crataegus monogyna by supercritical fluid extraction (CO2) using BoxBehnken experimental design, Journal of Supercritical Fluids, 81 (2013) 112-118.

[43] P.H. List, P.C. Schmidt, Phytopharmaceutical technology, Heyden \& Son Limeted, London, 1989.

585 [44] A.R.D. Costa, F.S. Marquiafavel, M.M.D.L.L. Vaz, B.A. Rocha, P.C.P. Bueno, P.L.M. Amaral, H.D. Barud, A. Ap Berreta-Silva, Quercetin-PVP K25 solid dispersions: Preparation, thermal characterization and antioxidant activity, Journal of Thermal Analysis and Calorimetry, 104 (2011) 273-278.

[45] L.E. Dowd, Spectrophotometric Determination of Quercetin, Analytical Chemistry, 31 $590 \quad$ (1959) 1184-1187.

[46] T.L. Miron, M. Plaza, G. Bahrim, E. Ibañez, M. Herrero, Chemical composition of bioactive pressurized extracts of Romanian aromatic plants, Journal of Chromatography A, 1218 (2011) 4918-4927. 
Cite as:

Costa-Machado, A. R. M.; Freitas, L. A. P. de; Mendiola, J. A.; Ibáñez, Elena "Copaifera langsdorffii supercritical fluid extraction: Chemical and functional characterization by LC/MS and in vitro assays" Journal of Supercritical Fluids 100: 86-96 (2015) http://dx.doi.org/10.1016/j.supflu.2015.02.028

[47] ICH, Validation of analytical procedures: text and methodology Q2(R1), in: International conference on harmonisation of technical requirements for registration of pharmaceuticals for human use, 2005.

[48] ANVISA. Agência Nacional de Vigilância Sanitária, Ministério da Saúde, RE 899, 29th may, 2003, Brasília, DF, Brasil.

[49] A.R.M. Costa-Machado, Obtenção de produtos a partir das folhas de Copaifera langsdorffii

Desf.: otimização da extração e secagem em spray dryer utilizando planejamentos experimentais, in:Departamento de Ciências Farmacêuticas, Universidade de São Paulo, Ribeirão Preto, 2011, pp. 115.

[50] J.P. de Sousa, M.F. Leite, R.F. Jorge, D.O. Resende, A.A. da Silva Filho, N.A. Furtado, A.E. Soares, A.C. Spadaro, P.M. de Magalhaes, J.K. Bastos, Seasonality role on the phenolics 605 from cultivated Baccharis dracunculifolia, Evidence-Based Complementary and Alternative Medicine, (2011) doi: 10.1093/ecam/nep077.

[51] A. Kazan, H. Koyu, I.C. Turu, O. Yesil-Celiktas, Supercritical fluid extraction of Prunus persica leaves and utilization possibilities as a source of phenolic compounds, Journal of Supercritical Fluids, 92 (2014) 55-59.

610 [52] W. Kukula-Koch, N. Aligiannis, M. Halabalaki, A.-L. Skaltsounis, K. Glowniak, E. Kalpoutzakis, Influence of extraction procedures on phenolic content and antioxidant activity of Cretan barberry herb, Food Chemistry, 138 (2013) 406-413.

[53] M. Herrero, M. Plaza, A. Cifuentes, E. Ibáñez, Green processes for the extraction of bioactives from Rosemary: Chemical and functional characterization via ultra-performance

615 liquid chromatography-tandem mass spectrometry and in-vitro assays, Journal of Chromatography A, 1217 (2010) 2512-2520.

[54] S. Siqueira, V.d.S. Falcão-Silva, M.d.F. Agra, C. Dariva, J.P.d. Siqueira-Júnior, M.J.V. Fonseca, Biological activities of Solanum paludosum Moric. extracts obtained by maceration and supercritical fluid extraction, Journal of Supercritical Fluids, 58 (2011) 391-397.

620 [55] Taylor \& Francis group, Dictionary of Natural Products, 19 November 2014. Available from: www.dnp.chemnetbase.com

[56] J.A. Rothwell, J. Pérez-Jiménez, V. Neveu, A. Medina-Ramon, N. M'Hiri, P. Garcia Lobato, C. Manach, K. Knox, R. Eisner, D. Wishart, A. Scalbert, Phenol-Explorer 3.0: a major update of the Phenol-Explorer database to incorporate data on the effects of food processing on polyphenol 625 content, Accessed in 19 November, 2014. Available from: http://phenol-explorer.eu/compounds. [57] C.A. RiceEvans, N.J. Miller, G. Paganga, Structure-antioxidant activity relationships of flavonoids and phenolic acids, Free Radical Biology and Medicine, 20 (1996) 933-956.

[58] J. Galvez, J.P. Delacruz, A. Zarzuelo, F.S. Demedina, J. Jimenez, F.S. Delacuesta, Oraladministration of quercitrin modifies intestinal oxidative status in rats, General Pharmacology, $630 \quad 25$ (1994) 1237-1243.

[59] P. Rodriguez, F. Gonzalez-Mujica, J. Bermudez, M. Hasegawa, Inhibition of glucose intestinal absorption by kaempferol 3-O-alpha-rhamnoside purified from Bauhinia megalandra leaves, Fitoterapia, 81 (2010) 1220-1223.

[60] R. Batista, P.A. García, M.A. Castro, J.M. Miguel del Corral, N.L. Speziali, F. de P. Varotti,

635 R.C. de Paula, L.F. García-Fernández, A.s. Francesch, A. San Feliciano, A.B. de Oliveira, Synthesis, cytotoxicity and antiplasmodial activity of novel ent-kaurane derivatives, European Journal of Medicinal Chemistry, 62 (2013) 168-176.

[61] R. Batista, J.L. Humberto, E. Chiari, A.d.B. de Oliveira, Synthesis and trypanocidal activity of ent-kaurane glycosides, Bioorganic \& Medicinal Chemistry, 15 (2007) 381-391. 
Cite as:

Costa-Machado, A. R. M.; Freitas, L. A. P. de; Mendiola, J. A.; Ibáñez, Elena "Copaifera langsdorffii supercritical fluid extraction: Chemical and functional characterization by LC/MS and in vitro assays" Journal of Supercritical Fluids 100: 86-96 (2015) http://dx.doi.org/10.1016/j.supflu.2015.02.028

640 [62] C.O. Rezende Jr, C. Rigotto, W. Caneschi, C.A.M. Rezende, M. Le Hyaric, M.R.C. Couri, C.M.O. Simões, M.V. de Almeida, Anti-HSV-1 and antioxidant activities of dicaffeoyl and digalloyl esters of quinic acid, Biomedicine \& Preventive Nutrition, 4 (2014) 35-38. 
Cite as:

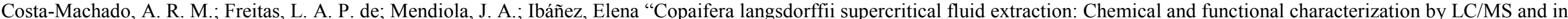
vitro assays" Journal of Supercritical Fluids 100: 86-96 (2015) http://dx.doi.org/10.1016/j.supflu.2015.02.028

\section{Tables}

Table 1. Figures of merit of the HPLC developed method for quantification of kaurenoic acid and quercitrin

\begin{tabular}{|l|c|c|c|c|c|c|c|c|}
\hline & $\begin{array}{c}\text { linear } \\
\text { range } \\
\mu \mathrm{g} / \mathrm{mL}\end{array}$ & Linear regression curve & $\mathrm{R}^{2}$ & \multicolumn{4}{|c|}{ Recovery test } & \multicolumn{2}{|c|}{ Analytical limits $(\mu \mathrm{g} / \mathrm{mL})$} \\
\cline { 5 - 9 } & $10-110$ & $\mathrm{y}=23.362 \mathrm{x}+46.646$ & 0.9997 & $98.0 \pm 4.0 \%$ & $100.0 \pm 2.8 \%$ & $104.5 \pm 3.1 \%$ & 0.443 & 1.341 \\
\hline $\begin{array}{l}\text { kaurenoic } \\
\text { acid }\end{array}$ & $1-40$ & $\mathrm{y}=98.104 \mathrm{x}-65.378$ & 0.9954 & $100.6 \pm 2.2 \%$ & $100.2 \pm 4.5 \%$ & $100.8 \pm 1.0 \%$ & 0.241 & 0.730 \\
\hline quercitrin & & & Low $(80 \%)$ & $\begin{array}{c}\text { Medium } \\
(100 \%)\end{array}$ & High (120\%) & LOD & LOQ \\
\hline
\end{tabular}


Cite as:

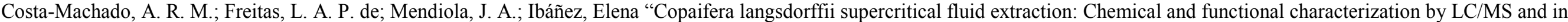
vitro assays" Journal of Supercritical Fluids 100: 86-96 (2015) http://dx.doi.org/10.1016/j.supflu.2015.02.028

Table 2. Responses evaluated for the standard extracts obtained using SLE.

\begin{tabular}{ccccccc}
\hline & $\begin{array}{c}\text { Yield } \\
(\% \mathrm{w} / \mathrm{w})\end{array}$ & $\begin{array}{c}\text { Total flavonoids } \\
(\mathrm{mg} / \mathrm{g})\end{array}$ & $\begin{array}{c}\text { Kaurenoic } \\
\text { acid }(\mathrm{mg} / \mathrm{g})\end{array}$ & $\begin{array}{c}\text { Quercitrin } \\
(\mathrm{mg} / \mathrm{g})\end{array}$ & $\begin{array}{c}E C_{50} \\
(\mu \mathrm{g} / \mathrm{mL})\end{array}$ & $\begin{array}{c}\text { TEAC } \\
(\mathrm{mmol} / \mathrm{g})\end{array}$ \\
\hline $\mathbf{A}$ & 31.83 & 20.587 & 24.136 & 9.610 & 9.074 & 2.737 \\
$\mathbf{B}$ & 34.18 & 24.229 & 25.869 & 10.369 & 10.280 & 2.438 \\
$\mathbf{C}$ & 36.30 & 24.529 & 21.778 & 10.259 & 8.148 & 2.472 \\
\hline
\end{tabular}


Cite as:

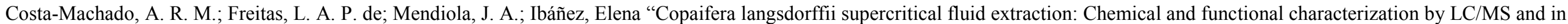
vitro assays" Journal of Supercritical Fluids 100: 86-96 (2015) http://dx.doi.org/10.1016/j.supflu.2015.02.028

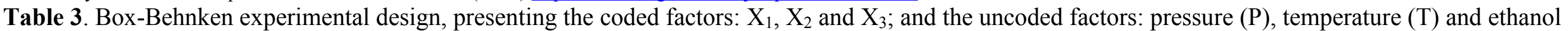
(E). Responses evaluated for the Box-Behnken experimental design.

\begin{tabular}{|c|c|c|c|c|c|c|c|c|c|}
\hline Run & $X_{1}(P)$ & $X_{2}(T)$ & $X_{3}(E)$ & $\begin{array}{c}\text { Yied } \\
(\% w / w)\end{array}$ & $\begin{array}{l}\text { Total flavonoids } \\
\text { ( } \mathrm{mg} / \mathrm{g})\end{array}$ & Kaurenoic acid (mg/g) & $\begin{array}{c}\text { Quercitrin } \\
\text { (mg/g) }\end{array}$ & $\begin{array}{c}E C_{50} \\
(\mu g / m L)\end{array}$ & $T E A C(\mathrm{mmol} / \mathrm{g})$ \\
\hline 1 & -1 (100 bar) & $-1\left(40^{\circ} \mathrm{C}\right)$ & $0(25 \%)$ & 8.33 & 72.569 & 103.982 & 10.493 & 14.118 & 0.982 \\
\hline 2 & +1 (400 bar) & $-1\left(40^{\circ} \mathrm{C}\right)$ & $0(25 \%)$ & 7.01 & 76.618 & 115.233 & 9.251 & 12.596 & 1.016 \\
\hline 3 & -1 (100 bar) & $+1\left(70^{\circ} \mathrm{C}\right)$ & $0(25 \%)$ & 14.50 & 50.918 & 73.127 & 13.151 & 10.162 & 1.182 \\
\hline 4 & +1 (400 bar) & $+1\left(70^{\circ} \mathrm{C}\right)$ & $0(25 \%)$ & 11.18 & 66.906 & 82.194 & 12.114 & 10.461 & 1.048 \\
\hline 5 & -1 (100 bar) & $0\left(55^{\circ} \mathrm{C}\right)$ & $-1(0 \%)$ & 0.31 & 0.657 & 81.063 & 7.468 & 131.726 & 0.244 \\
\hline 6 & +1 (400 bar) & $0\left(55^{\circ} \mathrm{C}\right)$ & $-1(0 \%)$ & 0.55 & 20.324 & 152.476 & 4.578 & 169.987 & 0.283 \\
\hline 7 & -1 (100 bar) & $0\left(55^{\circ} \mathrm{C}\right)$ & $+1(50 \%)$ & 12.28 & 59.356 & 69.818 & 11.859 & 11.540 & 1.173 \\
\hline 8 & +1 (400 bar) & $0\left(55^{\circ} \mathrm{C}\right)$ & $+1(50 \%)$ & 10.81 & 56.127 & 67.462 & 9.672 & 7.867 & 1.232 \\
\hline 9 & 0 (250 bar) & $-1\left(40^{\circ} \mathrm{C}\right)$ & $-1(0 \%)$ & 0.69 & 8.322 & 191.870 & 6.612 & 197.334 & 0.251 \\
\hline 10 & 0 (250 bar) & $+1\left(70^{\circ} \mathrm{C}\right)$ & $-1(0 \%)$ & 1.06 & 8.420 & 218.243 & 4.942 & 91.410 & 0.247 \\
\hline 11 & 0 (250 bar) & $-1\left(40^{\circ} \mathrm{C}\right)$ & $+1(50 \%)$ & 10.49 & 56.981 & 69.388 & 10.991 & 7.581 & 1.268 \\
\hline 12 & 0 (250 bar) & $+1\left(70^{\circ} \mathrm{C}\right)$ & $+1(50 \%)$ & 11.98 & 55.142 & 53.930 & 12.258 & 8.168 & 1.133 \\
\hline 13 & 0 (250 bar) & $0\left(55^{\circ} \mathrm{C}\right)$ & $0(25 \%)$ & 7.67 & 66.635 & 87.239 & 9.153 & 10.547 & 2.261 \\
\hline 14 & 0 (250 bar) & $0\left(55^{\circ} \mathrm{C}\right)$ & $0(25 \%)$ & 8.21 & 68.293 & 78.486 & 10.511 & 11.989 & 2.111 \\
\hline 15 & 0 (250 bar) & $0\left(55^{\circ} \mathrm{C}\right)$ & $0(25 \%)$ & 9.13 & 72.921 & 86.389 & 9.491 & 9.705 & 2.123 \\
\hline
\end{tabular}


Cite as:

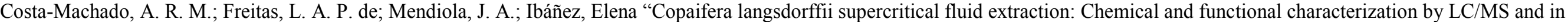
vitro assays" Journal of Supercritical Fluids 100: 86-96 (2015) http://dx.doi.org/10.1016/j.supflu.2015.02.028

Table 4. Model coefficients and regression adjustment of mathematical models obtained by Response Surface Methodology.

\begin{tabular}{|c|c|c|c|c|c|c|c|c|c|c|c|c|}
\hline \multirow[t]{2}{*}{ Effect } & \multicolumn{2}{|c|}{$\begin{array}{c}\text { Yield } \\
(\% w / w)\end{array}$} & \multicolumn{2}{|c|}{$\begin{array}{l}\text { Total flavonoids } \\
\text { ( } \mathrm{mg} / \mathrm{g})\end{array}$} & \multicolumn{2}{|c|}{$\begin{array}{c}\text { Quercitrin } \\
\text { (mg/g) }\end{array}$} & \multicolumn{2}{|c|}{ Kaurenoic acid $(\mathrm{mg} / \mathrm{g})$} & \multicolumn{2}{|c|}{$\begin{array}{c}E C_{50} \\
(\mu g / m L)\end{array}$} & \multicolumn{2}{|c|}{$\begin{array}{c}T E A C \\
(\mathrm{mmol} / \mathrm{g})\end{array}$} \\
\hline & Coefficients & $P$ & Coefficients & $P$ & Coefficients & $P$ & Coefficients & $P$ & Coefficients & $P$ & Coefficients & $P$ \\
\hline Intercept & 8.339 & 0.000 & 69.283 & 0.000 & 9.718 & 0.000 & 84.0380 & 0.007 & 10.747 & 0.317 & 2.165 & 0.000 \\
\hline$X_{1}^{2}$ & 0.899 & 0.307 & -0.315 & 0.911 & 0.614 & 0.364 & -15.5284 & 0.413 & 2.622 & 0.776 & -0.550 & $0.000^{*}$ \\
\hline$X_{2}$ & 1.551 & $0.034^{*}$ & -4.138 & 0.072 & 0.640 & 0.186 & -6.6223 & 0.599 & -13.929 & 0.066 & 0.012 & 0.709 \\
\hline$X_{2}^{2}$ & 1.016 & 0.254 & -2.215 & 0.446 & 0.920 & 0.195 & 25.1243 & 0.208 & -1.535 & 0.867 & -0.558 & $0.000 *$ \\
\hline$X_{3}^{2}$ & -3.249 & $0.009 *$ & -34.852 & $0.000 *$ & -1.938 & $0.025^{*}$ & 24.1951 & 0.223 & 66.911 & $0.001 *$ & -0.882 & $0.000 *$ \\
\hline$X_{1} * X_{2}$ & -0.499 & 0.539 & 2.985 & 0.299 & 0.051 & 0.934 & -0.5461 & 0.975 & 0.455 & 0.959 & -0.042 & 0.367 \\
\hline$X_{1} * X_{3}$ & -0.428 & 0.597 & -5.724 & 0.077 & 0.176 & 0.778 & -18.4423 & 0.320 & -10.484 & 0.266 & 0.005 & 0.914 \\
\hline$X_{2} * X_{3}$ & 0.232 & 0.772 & -0.484 & 0.858 & 0.734 & 0.269 & -10.4576 & 0.559 & 26.628 & $0.025 *$ & -0.033 & 0.475 \\
\hline$R^{2}$ & 0.963 & - & 0.986 & - & 0.927 & - & 0.829 & - & 0.977 & - & 0.994 & - \\
\hline$R^{2}$ adjusted & 0.898 & - & 0.961 & - & 0.795 & - & 0.521 & - & 0.936 & - & 0.984 & - \\
\hline Lack of fit & 0.138 & - & 0.230 & - & $0.003 *$ & - & 0.207 & - & $0.012 *$ & - & 0.519 & - \\
\hline
\end{tabular}

* significant values 
Cite as:

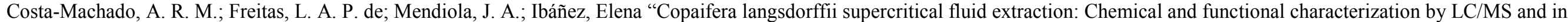
vitro assays" Journal of Supercritical Fluids 100: 86-96 (2015) http://dx.doi.org/10.1016/j.supflu.2015.02.028

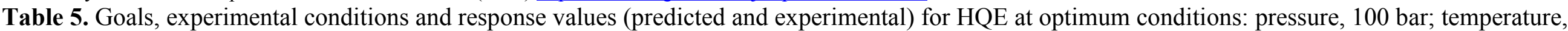
$70^{\circ} \mathrm{C}$ and $50 \%$ ethanol as modifier.

\begin{tabular}{l|cccccccc}
\hline Responses & Goal & Lower & Target & Upper & Weight & Desirability & Predicted & Real \\
\hline Yield $(\% \mathrm{w} / \mathrm{w})$ & Max & 0.30 & 15.0 & 15.0 & 1 & 1.000 & 17.07 & $16.34 \pm 3.09$ \\
Total & Max & 0.65 & 77.0 & 77.0 & 1 & 0.695 & 53.73 & $53.28 \pm 6.08$ \\
flavonoids $(\mathrm{mg} / \mathrm{g})$ & & & & & & & & \\
EC $_{50}(\mu \mathrm{g} / \mathrm{mL})$ & Min & 7.50 & 7.50 & 197.00 & 1 & 0.999 & 7.53 & $10.52 \pm 2.23$ \\
Quercitrin $(\mathrm{mg} / \mathrm{g})$ & Max & 4.50 & 13.00 & 13.00 & 1 & 1.000 & 14.66 & $15.22 \pm 2.06$ \\
\hline
\end{tabular}


Cite as:

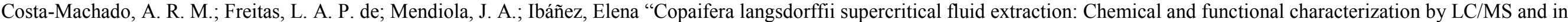
vitro assays" Journal of Supercritical Fluids 100: 86-96 (2015) http://dx.doi.org/10.1016/j.supflu.2015.02.028

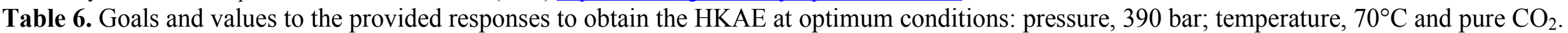

\begin{tabular}{l|cccccccc}
\hline Responses & Goal & Lower & Target & Upper & Weight & Desirability & Predicted & Real \\
\hline $\begin{array}{l}\text { Kaurenoic } \\
\text { acid }(\mathrm{mg} / \mathrm{g})\end{array}$ & Max & 67.50 & 218.20 & 218.20 & 1 & 0.870 & 198.68 & $262.92 \pm 14.28$ \\
\hline
\end{tabular}


Cite as:

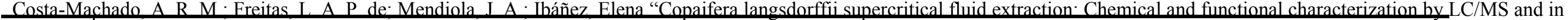

\begin{tabular}{|c|c|c|c|c|c|c|c|}
\hline number & $(\min )$ & $M W$ & $m / z-$ & $\lambda_{\max }(\mathrm{nm})$ & Proposed compound & $m / z-$ & Proposed Fragment \\
\hline 1 & 2.82 & - & 386.99 & $225 / 266(s)$ & NI & 341.04 & NI \\
\hline 2 & 4.11 & 358.27 & 356.90 & $225 / 276$ & galloylquinic acid with 1 methyl group & $\begin{array}{l}191.02 \\
183.01 \\
172.92\end{array}$ & $\begin{array}{l}\text { quinic acid } \\
\text { methyl gallate } \\
\text { gallic acid }\end{array}$ \\
\hline 3 & 4.52 & 358.27 & 356.90 & $225 / 276$ & galloylquinic acid with 1 methyl group & $\begin{array}{l}190.98 \\
182.94 \\
173.07\end{array}$ & $\begin{array}{l}\text { quinic acid } \\
\text { methyl gallate } \\
\text { gallic acid }\end{array}$ \\
\hline 4 & 5.25 & 358.27 & 356.90 & $225 / 277$ & galloylquinic acid with 1 methyl group & 191.09 & quinic acid \\
\hline 5 & 7.52 & 510.37 & 509.06 & $225 / 277$ & di-galloylquinic acid with 1 methyl group & 356.94 & galloylquinic acid with 1 methyl \\
\hline 6 & 7.62 & 510.37 & 509.05 & $226 / 277$ & di-galloylquinic acid with 1 methyl group & 356.94 & galloylquinic acid with 1 methyl \\
\hline \multirow{2}{*}{7} & \multirow{2}{*}{8.14} & \multirow{2}{*}{510.37} & \multirow{2}{*}{509.09} & \multirow{2}{*}{$225 / 276$} & \multirow{2}{*}{ di-galloylquinic acid with 1 methyl group } & 356.94 & galloylquinic acid with 1 methyl \\
\hline & & & & & & 342.92 & galloylquinic acid \\
\hline \multirow{2}{*}{8} & \multirow{2}{*}{9.85} & \multirow{2}{*}{524.37} & \multirow{2}{*}{523.06} & \multirow{2}{*}{$226 / 276$} & \multirow{2}{*}{ di-galloylquinic acid with 2 methyl groups } & 356.93 & galloylquinic acid with 1 methyl \\
\hline & & & & & & 338.92 & galloylquinic acid with 1 methyldehydrated \\
\hline \multirow{2}{*}{9} & \multirow{2}{*}{9.90} & \multirow{2}{*}{524.37} & \multirow{2}{*}{523.06} & \multirow{2}{*}{$226 / 276$} & \multirow{2}{*}{ di-galloylquinic acid with 2 methyl groups } & 356.95 & galloylquinic acid with 1 methyl \\
\hline & & & & & & 338.94 & galloylquinic acid with 1 methyldehydrated \\
\hline 10 & 11.12 & 524.37 & 523.06 & $226 / 276$ & di-galloylquinic acid with 2 methyl groups & 356.93 & galloylquinic acid with 1 methyl \\
\hline
\end{tabular}

Table 7.

Results of

the LC/MS

analysis

from the

HQE in

the

negative mode. 
Cite as:

Costa-Machado, A. R. M.; Freitas, L. A. P. de; Mendiola, J. A.; Ibáñez, Elena "Copaifera langsdorffii supercritical fluid extraction: Chemical and functional characterization by LC/MS and in vitro assays" Journal of Supercritical Fluids 100: 86-96 (2015) http://dx.doi.org/10.1016/j.supflu.2015.02.028

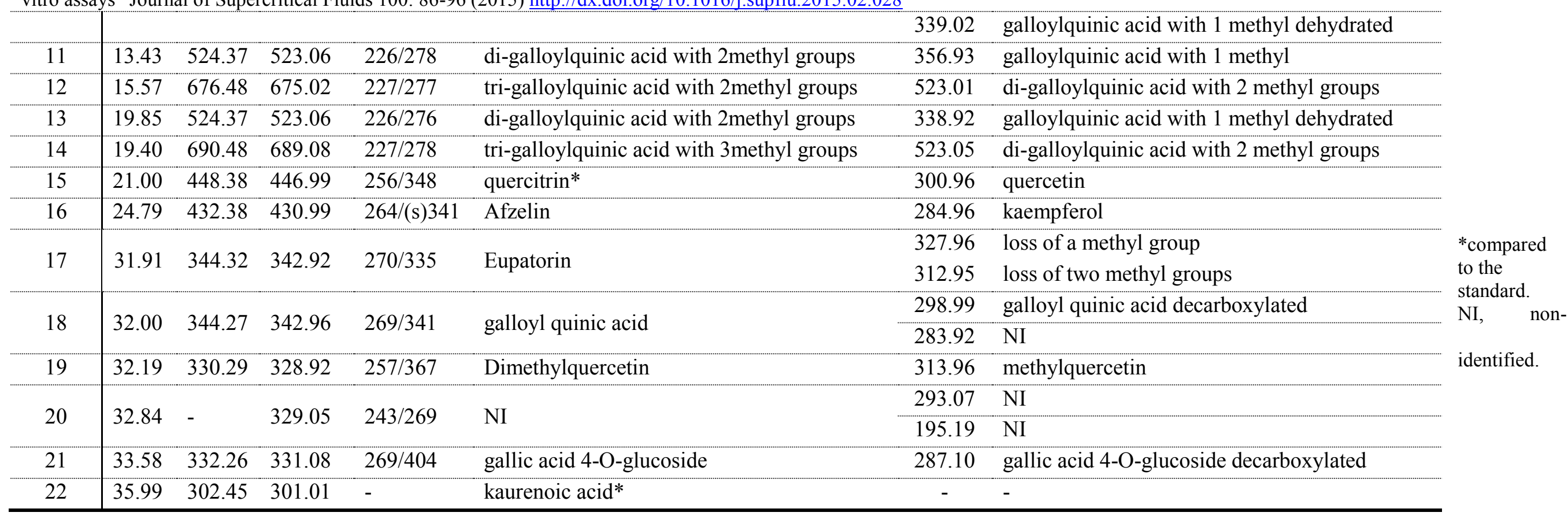




\section{Cite as:}

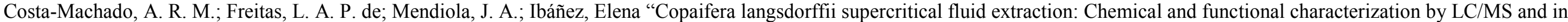
vitro assays” Journal of Supercritical Fluids 100: 86-96 (2015) http://dx.doi.org/10.1016/j.supflu.2015.02.028

\section{Figures}
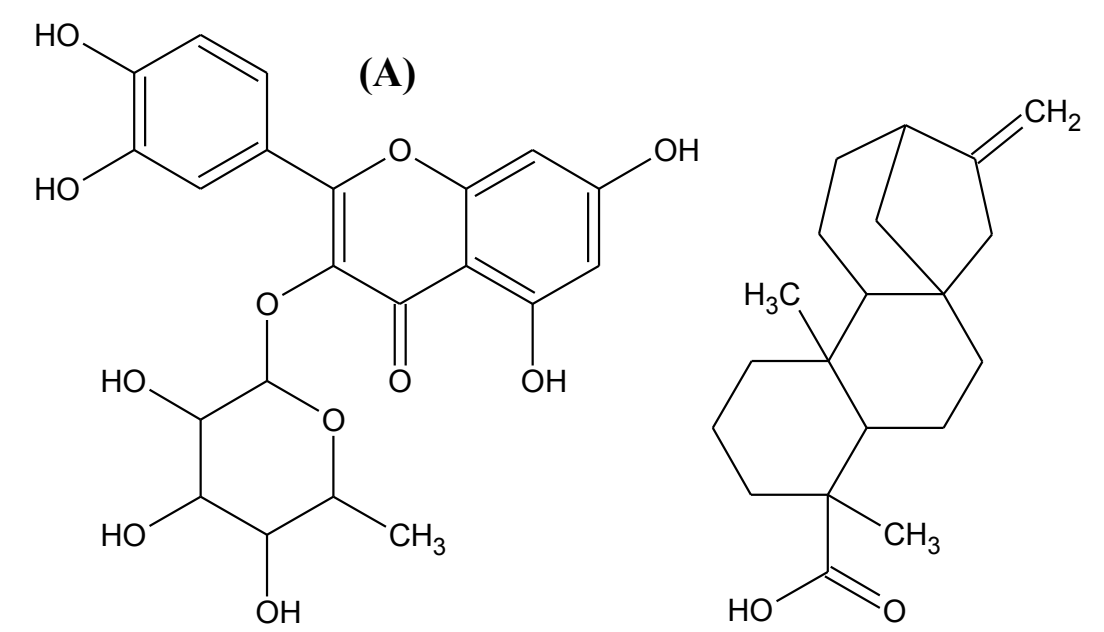

(B)

Figure 1. Chemical structures of (A) quercitrin and (B) kaurenoic acid. 


\section{Cite as:}

Costa-Machado, A. R. M.; Freitas, L. A. P. de; Mendiola, J. A.; Ibáñez, Elena "Copaifera langsdorffii supercritical fluid extraction: Chemical and functional characterization by LC/MS and in vitro assays" Journal of Supercritical Fluids 100: 86-96 (2015) $\underline{\text { http://dx.doi.org/10.1016/j.supflu.2015.02.028 }}$
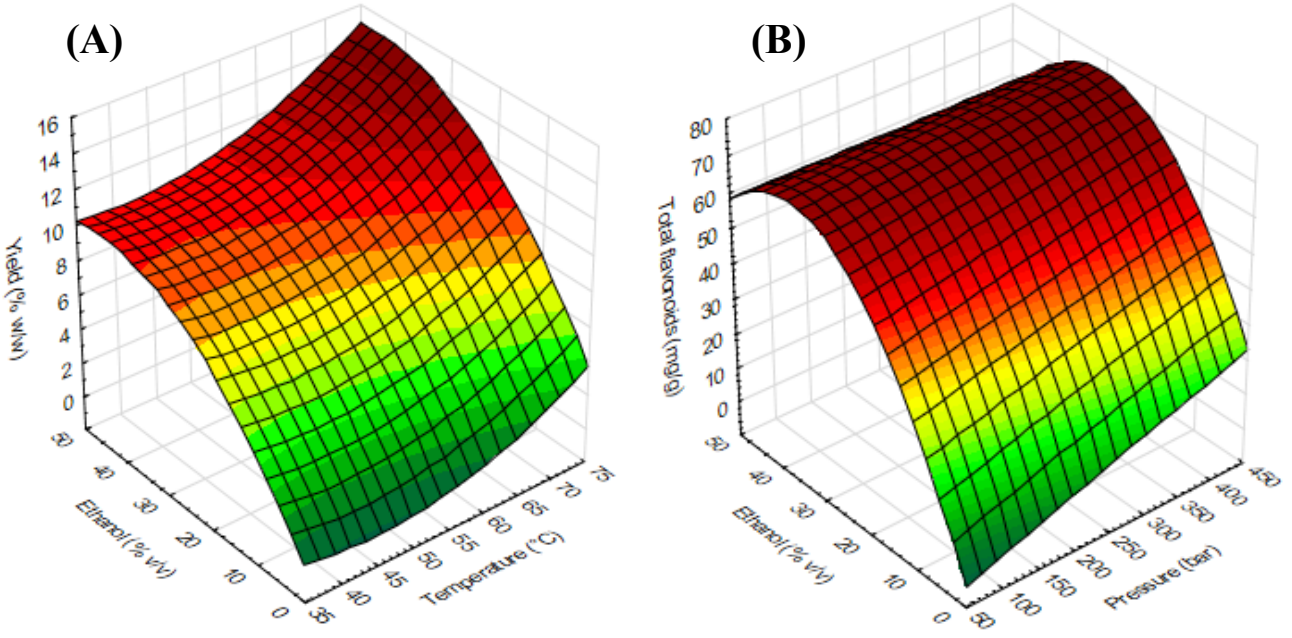


\section{Cite as:}

Costa-Machado, A. R. M.; Freitas, L. A. P. de; Mendiola, J. A.; Ibáñez, Elena "Copaifera langsdorffii supercritical fluid extraction: Chemical and functional characterization by LC/MS and in vitro assays" Journal of Supercritical Fluids 100: 86-96 (2015) http://dx.doi.org/10.1016/j.supflu.2015.02.028
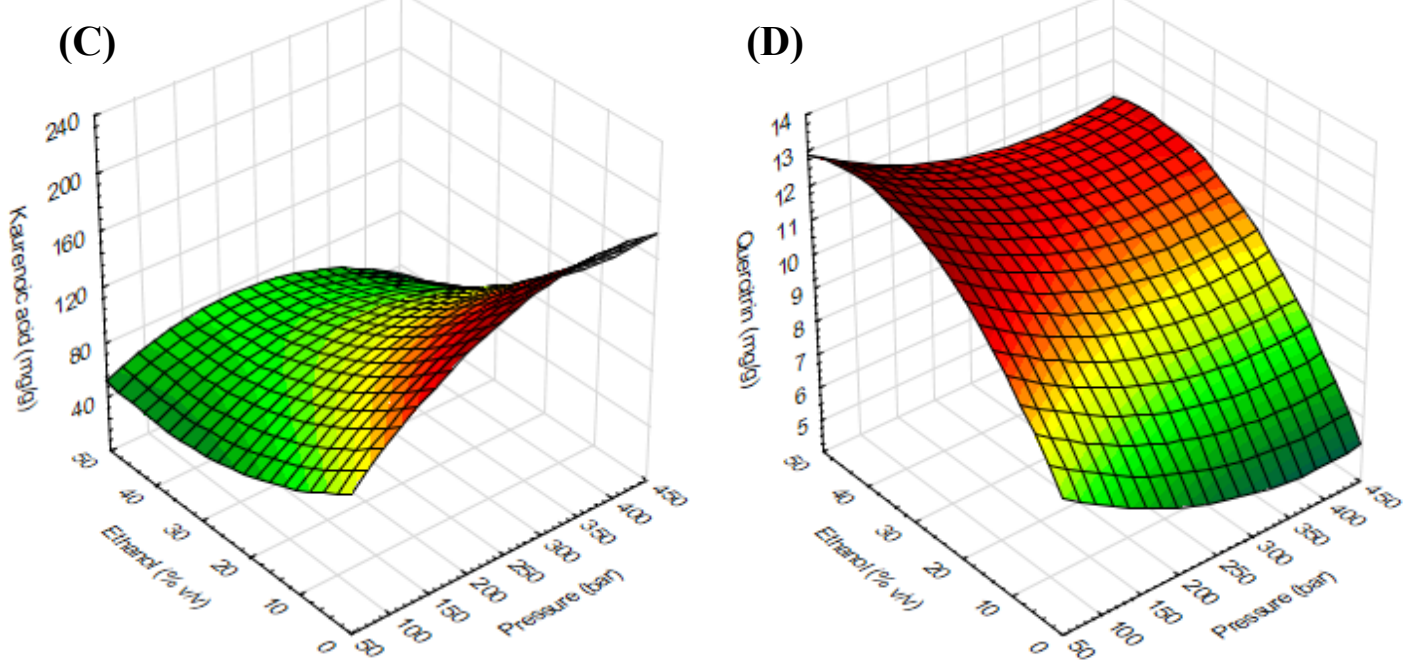


\section{Cite as:}

Costa-Machado, A. R. M.; Freitas, L. A. P. de; Mendiola, J. A.; Ibáñez, Elena "Copaifera langsdorffii supercritical fluid extraction: Chemical and functional characterization by LC/MS and in vitro assays" Journal of Supercritical Fluids 100: 86-96 (2015) http://dx.doi.org/10.1016/j.supflu.2015.02.028
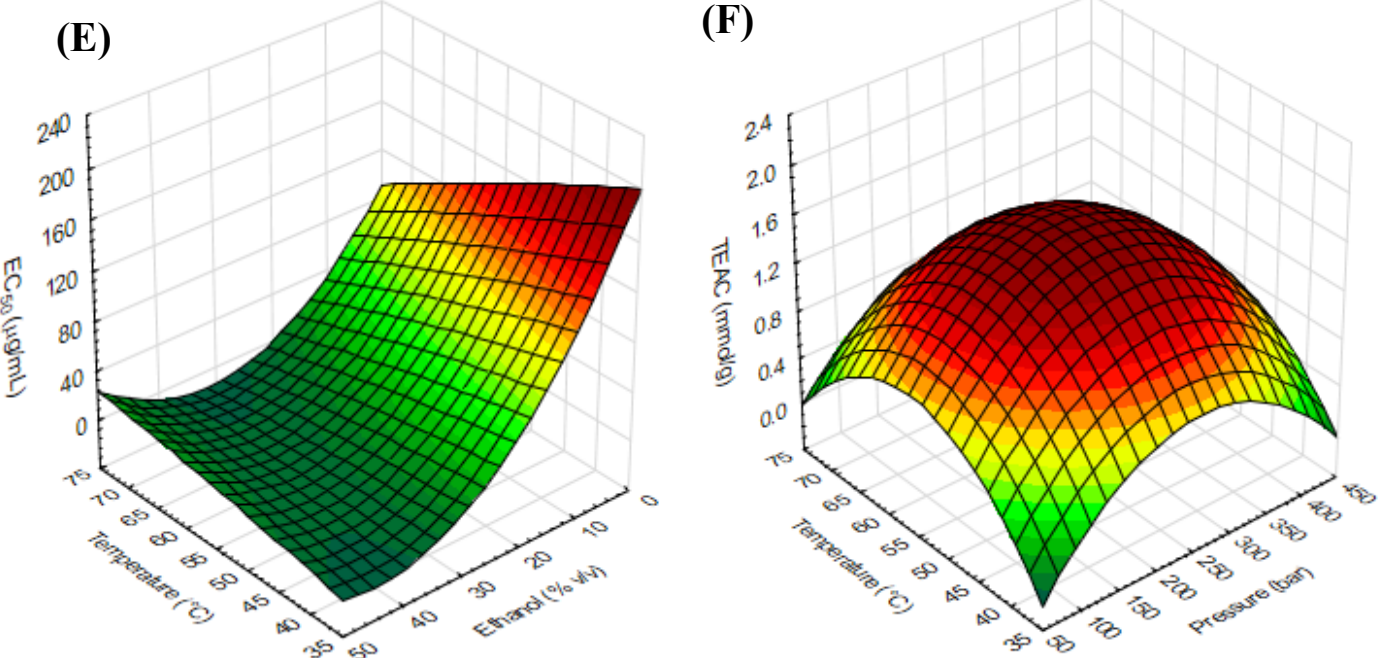

Figure 2. Response surface for (A) yield, (B) total flavonoids, (C) kaurenoic acid, (D) quercitrin, (E) EC 50 for DPPH and (F) TEAC. 


\section{Cite as:}

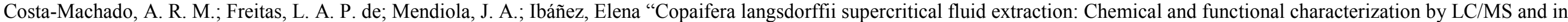
vitro assays" Journal of Supercritical Fluids 100: 86-96 (2015) http://dx.doi.org/10.1016/j.supflu.2015.02.028
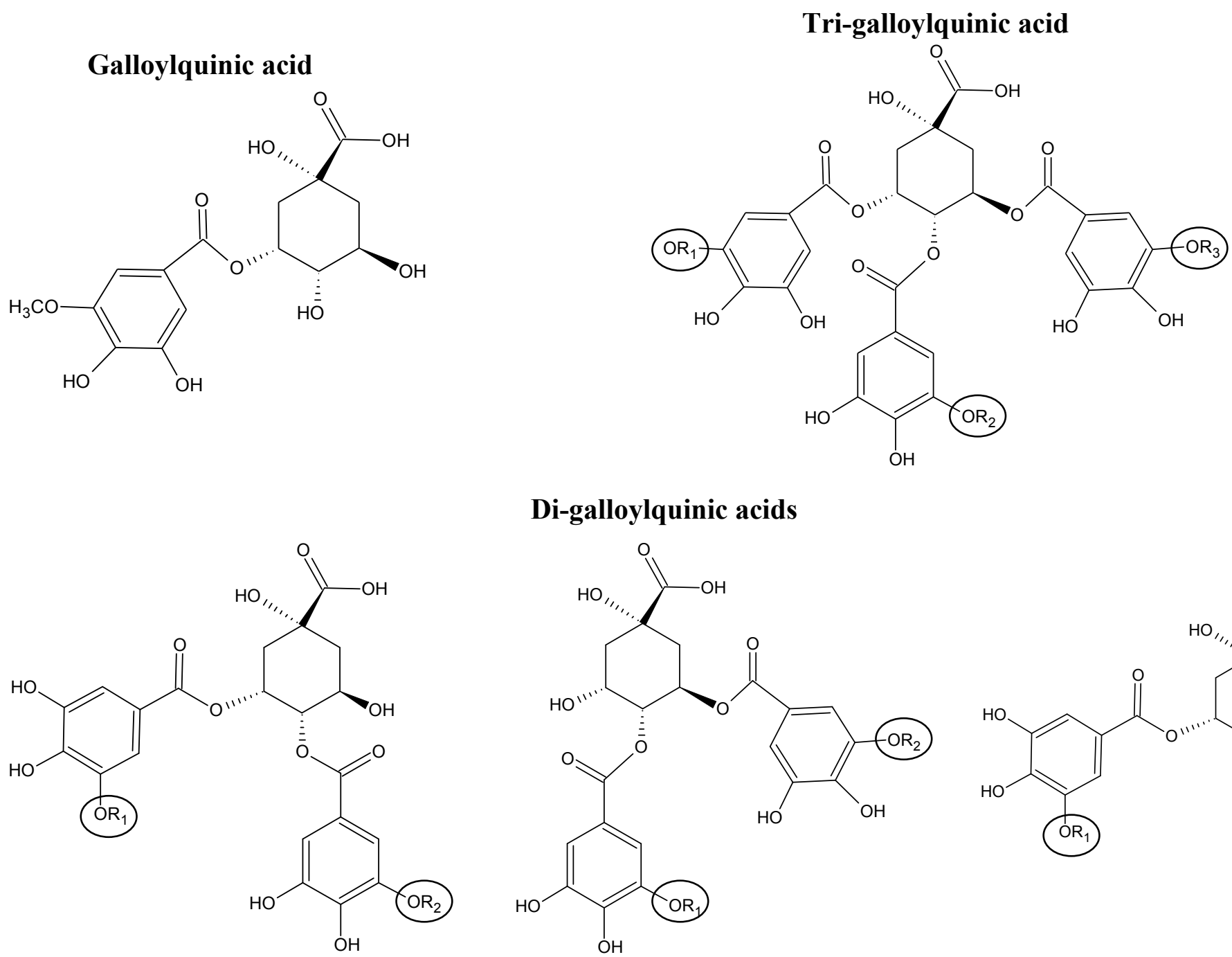

\section{Di-galloylquinic acids}
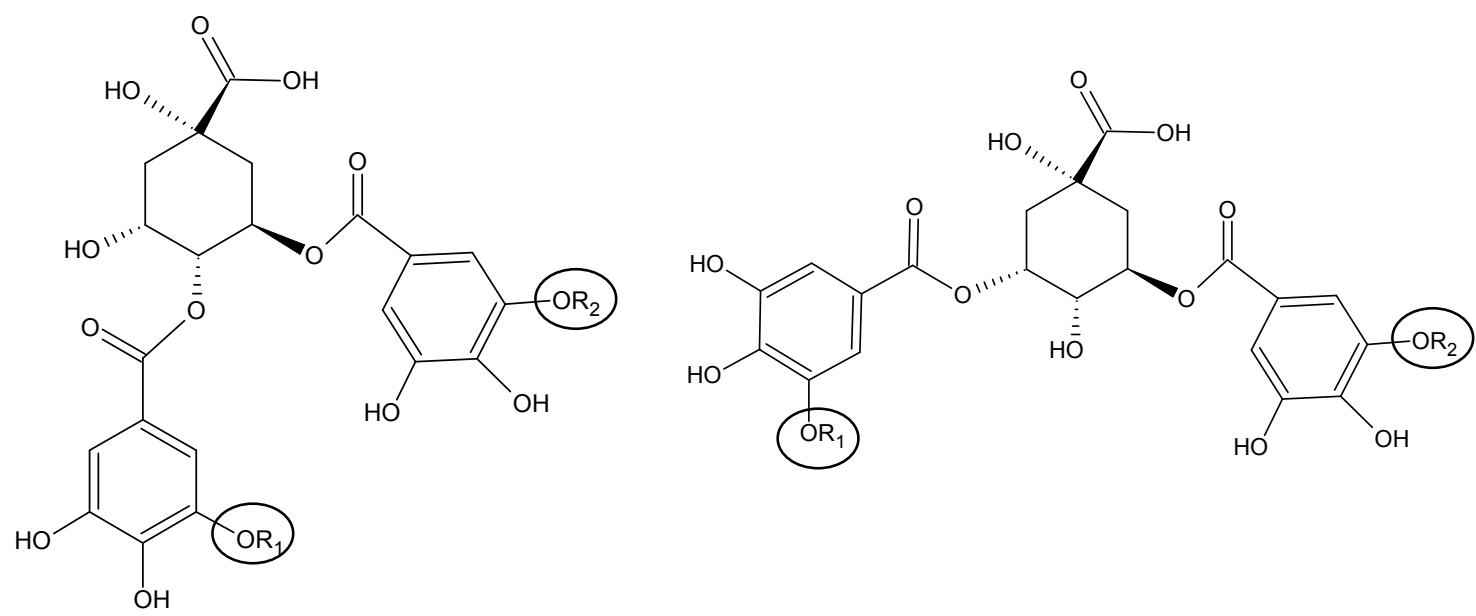


\section{Cite as:}

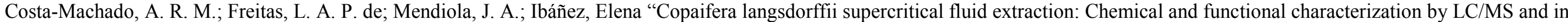
vitro assays" Journal of Supercritical Fluids 100: 86-96 (2015) http://dx.doi.org/10.1016/j.supflu.2015.02.028

Figure 3. Representative chemical structures of galloylquinic acids involved in this study. $R_{1}, R_{2}$ and $R_{3}$ can be hydrogen or methyl group. 